\title{
TWO NEW SPECIES OF ECHINOSEPALA (ORCHIDACEAE: PLEUROTHALLIDINAE)
}

\author{
Franco Pupulin ${ }^{1-3,5}$, Adam P. Karremans ${ }^{1,4} \&$ Noelia Belfort Oconitrillo ${ }^{1}$ \\ ${ }^{1}$ Jardín Botánico Lankester, Universidad de Costa Rica. P.O. Box 302-7050 Cartago, Costa Rica. \\ ${ }^{2}$ Harvard University Herbaria, Cambridge, MA, U.S.A. \\ ${ }^{3}$ The Marie Selby Botanical Gardens, Sarasota, FL, U.S.A. \\ ${ }^{4}$ Naturalis Biodiversity Center - Leiden University, The Netherlands \\ ${ }^{5}$ Author for correspondence: franco.pupulin@ucr.ac.cr
}

\begin{abstract}
We describe and illustrate two new species of Echinosepala from Costa Rica, they are placed within a phylogenetic framework of the genus, and compared to their closest relatives. A short resume of the genus' history is given, reviewing the main characters that have been used to group its species at various taxonomic ranks. Echinosepala expolita is compared with E. pan, from which it mainly differs by the glabrous, inflated sheaths that cover the ramicaul, the distinctly broader ligulate-lanceolate leaves, the lanate-hirsute ovary, the much larger flower, and the tomentose abaxial indumentum of the sepals. Echinosepala longipedunculata is similar to $E$. aspasicensis, but can be recognized by the unusually long peduncle, the greenish yellow flower, the verrucosetuberculate adaxial surface of the sepals, and the shorter, truncate, orange lip. A key to the Costa Rican species of Echinosepala is provided. A new combination in Echinosepala is proposed for Acianthera biseta from Peru.

Resumen. Se describen e ilustran dos nuevas especies de Echinosepala de Costa Rica, discutiéndolas dentro del marco filogenético del género y comparándolas con sus parientes más cercanos. Retomamos brevemente la historia del género, revisando los principales caracteres que han sido utilizados para agrupar sus especies en diferentes rangos taxonómicos. Echinosepala expolita se compara con E. pan, de la cual difiere principalmente por las vainas glabras e infladas que cubren el ramicaule, las hojas distintamente ligulado-lanceoladas, el ovario lanado-hirsuto, la flor mucho más grande y la indumentaria abaxial tomentosa de los sépalos. Echinosepala longipedunculata es similar a E. aspasicensis, pero puede ser reconocida por el pedúnculo inusualmente largo, las flores amarillo-verdosas, la superficie adaxial verrugosa-tuberculosa de los sépalos y el labelo más corto, truncado y de color naranja. Se proporciona una clave taxonómica para las especies costarricenses de Echinosepala. Se propone una nueva combinación en Echinosepala para Acianthera biseta.
\end{abstract}

Key words: Acianthera, Echinosepala aspasicensis, Echinosepala pan, flora of Costa Rica, Myoxanthus, new species, phylogenetics, pseudo-glenion

Introduction. Among the groups of "basal" Pleurothallidinae (sensu Karremans 2016), few other genera have been so difficult to place into a correct phylogenetic context as Echinosepala Pridgeon \& M.W.Chase. Of the twelve to fourteen species belonging to the genus (IPNI 2017, Epidendra 2017), none were originally described in Echinosepala: one was proposed in Acianthera Scheidw., two in Myoxanthus Poepp. \& Endl., and 11 in Pleurothallis R.Br. When Carlyle Luer (1992) first recognized that most species of the group were closely related and gathered them into Myoxanthus subgen. Silenia Luer (typified by Pleurothallis aspasicensis Rchb.f.) and Myoxanthus subgen. Satyria Luer (typified by Pleurothallis pan Luer), all the species of Echinosepala but five had already been described as members of Pleurothallis. Luer (1992) distinguished subgen. Satyria and subgen. Silenia from other groups of Myoxanthus by the nonscurfy sheaths [except Myoxanthus pan (Luer) Luer $\equiv$ Echinosepala pan (Luer) Pridgeon \& M.W.Chase], and the flowers produced from low on the ramicaul or terminally at the base of the leaf (instead of from near 

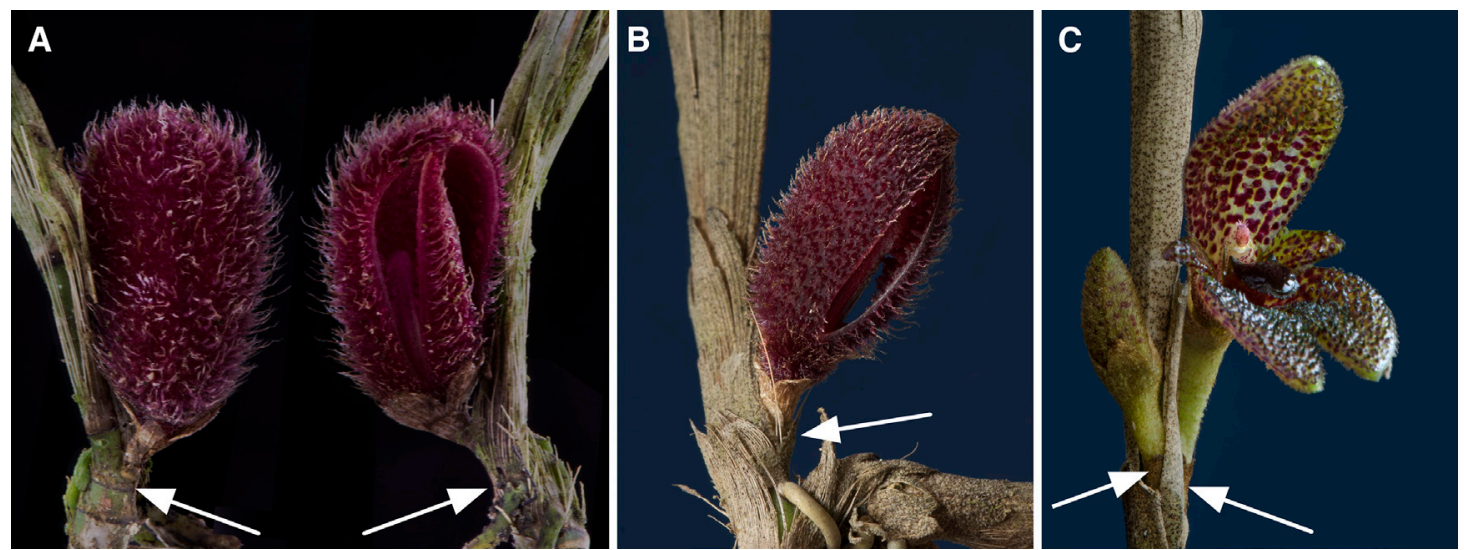

Figure 1. Basal inflorescences in species of Echinosepala. Note that the peduncle is exserted from a node of the stem (arrows). A, E. lappiformis (Bogarín 890). B, E. stonei (Bogarin 1871). C, E. expolita (Bogarín 1871). All the vouchers at JBL. Photographs by F. Pupulin.

the apex of the stem). The conspicuously verrucoseciliate upper margin of the anther cap, although not unique to these species, is a common synapomorphy of the two subgenera. Considering that the species of Myoxanthus subgenera Satyria and Silenia had greater affinities with Pleurothallis subgenus Acianthera (Scheidw.) Luer, Luer (1995) moved most species back to Pleurothallis, demoting the two subgenera to sections within the subgen. Acianthera (Luer 1995, validated in Luer 1996). Before recombining some leftover species in Echinosepala (Luer 2007), Luer also suggested an affinity of the genus with Kraenzlinella Kuntze, transferring to it his Pleurothallis shuarii (Luer 1982, 2004). The analyses of DNA data (Pridgeon, Solano \& Chase 2001, Pridgeon \& Chase 2001) confirmed that the species of Myoxanthus subgen. Silenia and subgen. Satyria form a monophyletic group deserving generic recognition, and Pridgeon and Chase (2001) gave it formal status by creating Echinella Pridgeon \& M.W.Chase [later corrected to Echinosepala Pridgeon \& M.W.Chase (2002)].

The phylogenetic analyses also confirmed a close relationship between Echinosepala and Myoxanthus, as originally noted by Luer on the basis of morphological similarities. These two genera, together with Barbosella Schltr., Dresslerella Luer, Pleurothallopsis Porto \& Brade, Restrepia Kunth, and Restrepiella Garay \& Dunst., form one of the nine major affinities within the Pleurothallidinae, sister to the "basal" clade of Octomeria R.Br., and consecutively sister to the Acianthera clade.

Morphologically, the species of Echinosepala LANKESTERIANA 17(2). 2017. (C) Universidad de Costa Rica, 2017. are characterized by caespitose to repent plants with monophyllous ramicauls covered by tubularancipitous, minutely warty to pubescent sheaths; the leaf coriaceous; the inflorescence solitary-flowered, produced from the apical or lower nodes of the stem; the flower fleshy, with the sepals frequently hirsute abaxially and variously verrucose adaxially, the lateral sepals connate into a concave to cymbiform synsepal; the lip 3-lobed, with a high basal callus and with erect lateral lobes oblong to uncinate; the anther apical, incumbent, the anther cap papillose to ciliate at the apex; pollinia 2, with whale-tail shaped caudiculae (Luer 1992, Pridgeon 2005a).

The point of insertion of the inflorescence along the stem has been used as the main character to distinguish two assemblages of species within the group. Luer (1992) originally created subgen. Satyria of Myoxanthus to separate those species with a basal inflorescence, erroneously reported as produced from the rhizome (e.g., Luer 1992, Dressler 1993, Luer 2003, Pridgeon 2005a), from the rest of the group, which supposedly has a terminal inflorescence. Actually, the inflorescences of Echinosepala species are never rhizomic, and it is dubious that flowering from the nodes of the rhizome occurs at all in the Pleurothallidinae. The stem (ramicaul) of Echinosepala species is composed of 4 to 5 internodes which are completely enfolded by large, compressed-ancipitous, dry-papyraceous sheaths, the upper ones somewhat looser. Once the sheaths are removed, it is easy to observe that the basal inflorescence is produced along the stem, where it is exserted from the apex of the second to third internode (Fig. 1). The 


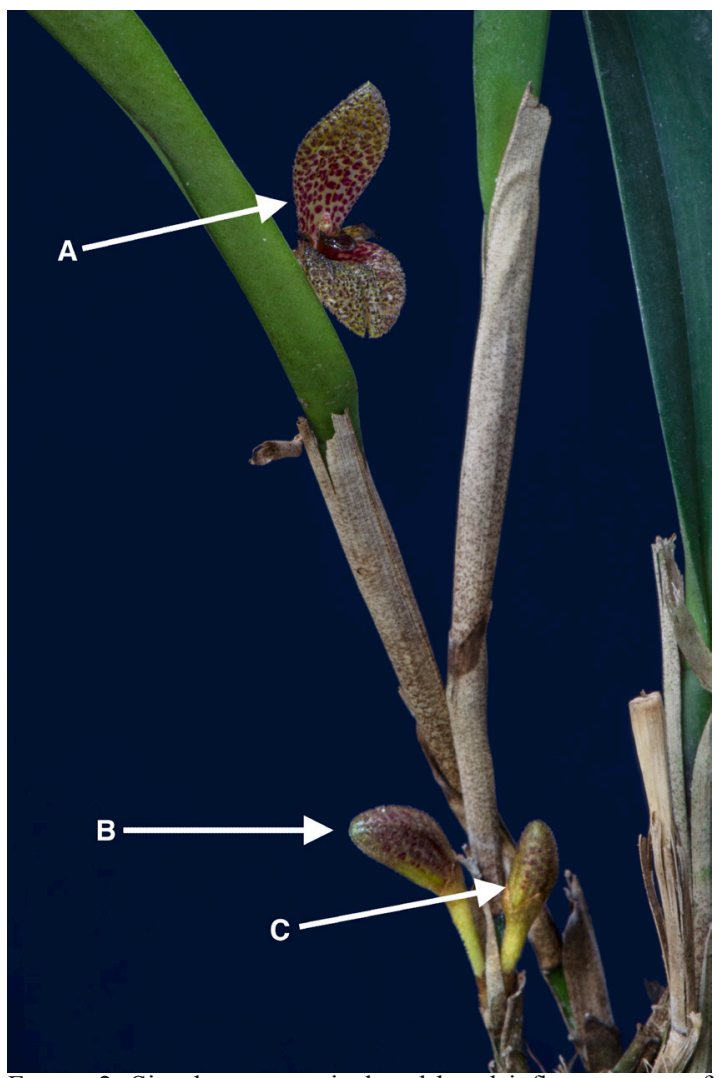

FIgURE 2. Simultaneous apical and basal inflorescences of

E. expolita (arrows) (Pupulin 7030, JBL). Photograph by F. Pupulin.

production of the inflorescence from the lower nodes of the stem is apparently an obligate feature in $E$. lappiformis (A.H.Heller \& L.O.Williams) Pridgeon \& M.W.Chase, E. pan, and E. stonei (Luer) Pridgeon \& M.W.Chase, but it is facultative in the species hereafter described as E. expolita, where both apical and basal inflorescences can be produced at once (Fig. 2). This condition has evolved in other groups of Pleurothallids, like Acianthera, and even in Echinosepala it could have arisen independently in two different groups of species.

The "basal" position of the inflorescence in species of Echinosepala convinced Luer (2004) to revive the genus Brenesia Schlechter (1923), originally coined to accommodate the anomalous Brenesia costaricensis Schltr., a species with a pendent inflorescence produced from the lower nodes of the ramicaul bearing hirsute flowers, and to transfer to Brenesia eight species previously treated under Echinosepala (Luer 2004), as well as Pleurothallis johnsonii Ames [三Acianthera johnsonii (Ames) Pridgeon \& M.W.Chase], in the belief that they were related to each other. However, the relationship between species of Brenesia stricto sensu [i.e., B. costaricensis, B. herrerae (Luer) Luer, $B$. johnsonii (Ames) Luer + Acianthera sotoana Solano] and species of Echinosepala was not supported by the DNA analysis carried out by Pridgeon and collaborators (2001). More recently, a broad phylogenetic analysis of Acianthera (Karremans et al. 2016) showed that the clade including the type species of Brenesia is sister to a clade that includes Antilla (Luer) Luer and Kraenzlinella, altogether highly supported as sisters to the rest of Acianthera. The four Central American species of true "Brenesia" were formally recognized as a group with subgeneric status as Acianthera subgen. Brenesia (Schltr.) Karremans (Karremans et al. 2016).

Florally, species of Echinosepala are mostly characterized by the putrid color of the bilabiate perianth, often spreading only partially, and the complicated abaxial indumenta of the sepals. The indumentum varies from sparsely warty-verruculose $[E$. aspasicensis, E. sempergemmata (Luer) Pridgeon \& M.W.Chase, E. uncinata (Fawc.) Pridgeon \& M.W.Chase], the warts sometimes grouped into small tufts $[E$. longipedunculata, hereafter, and E. vittata (Pupulin \& M.A.Blanco) C.O.Morales \& N.Villalobos]; to sparsely spiny (E. expolita, hereafter); densely tomentose $[E$. tomentosa (Luer) Pridgeon \& M.W.Chase]; hirsute with soft trichomes [E. lappiformis (A.H.Heller \& L.O.Williams) Pridgeon \& M.W.Chase, E. stonei (Luer) Pridgeon \& M.W.Chase]; or echinate with stiff hairs (E. pan). Adaxially, the sepals are almost glabrous ( $E$. aspasicensis, E. sempergemmata, E. uncinata, E. vittata); sparsely warty (E. tomentosa); to covered with irregular, low (E. lappiformis) or high (E. stonei) verrucae, or stiff, short, rounded (E. longipedunculata) or pointed (E. expolita, E. pan) warts. In two species the base of the dorsal sepal is semitransparent (E. aspasicensis, E. expolita), forming a window under the dark purple blotches (Fig. 3). The petals are mostly glabrous to sparsely verruculose, but they may be distinctly warty toward the apex (E. expolita, E. lappiformis, E. pan, E. stonei). The lip is glabrous in most species, but it is warty at the apex in E. sempergemmata and E. shuarii (Luer) Luer. At the base, it always presents a high callus which can be rounded and broad, massive, slightly concave, smooth or transversely rugose, occupying the entire 

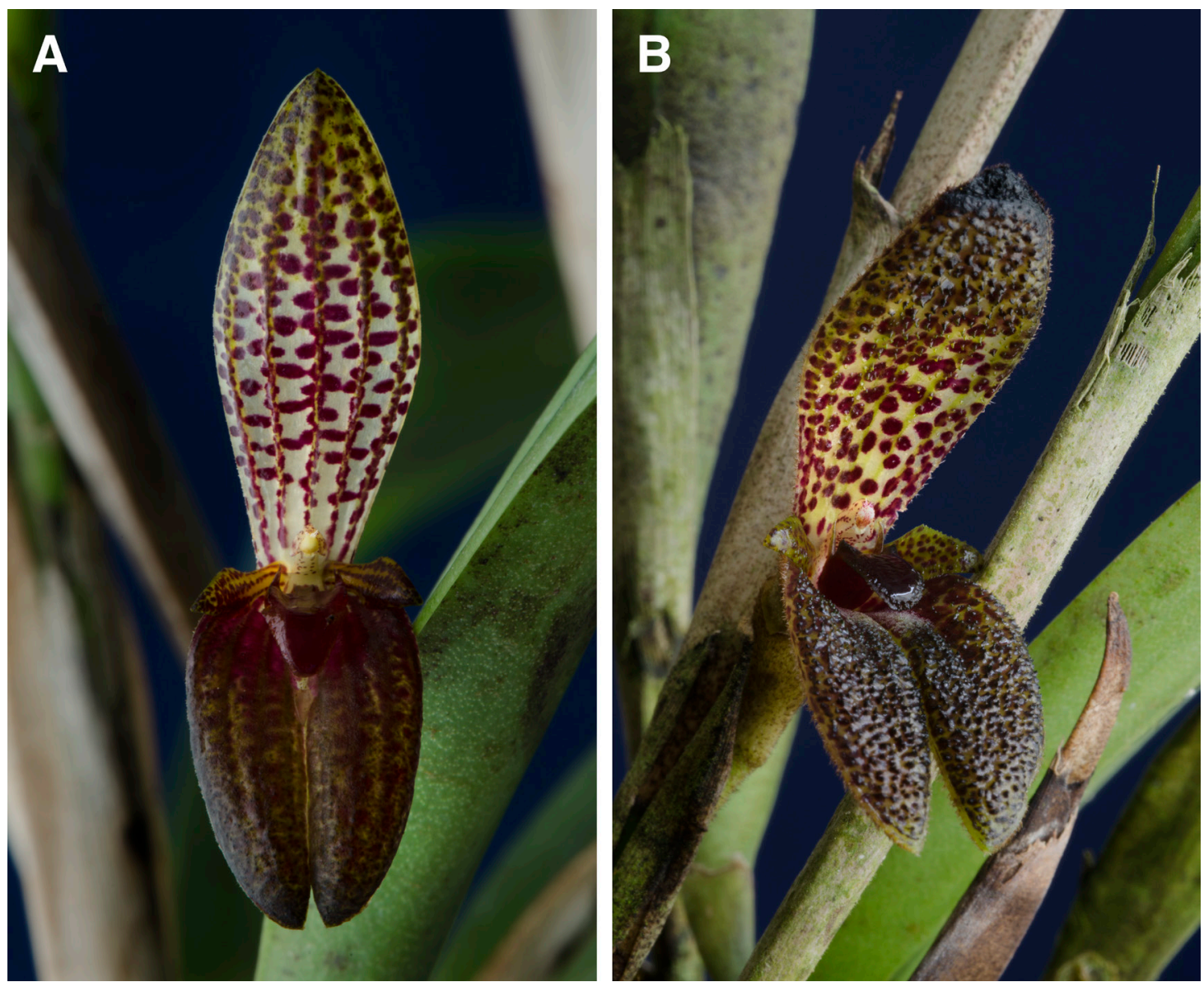

Figure 3. Fenestrate dorsal sepal in E. aspasicensis (A, Karremans 4407) and E. expolita (B, Bogarín 1871). Vouchers at JBL. Photographs by F. Pupulin.

lip base (E. lappiformis, E. sempergemmata, E. stonei, $E$. uncinata), or provided with a horseshoe-shaped, concave pseudo-glenion (E. aspasicensis, E. expolita, E. longipedunculata, E. pan, E. tomentosa, E. vittata). While true glenions in the Pleurothallidinae are rounded to elliptic to horsehoe-shaped depressions, often on the top of a raised area at the base of the lip, which apparently do not produce any exudates, the structure here defined as a pseudo-glenion is distinctly raised above the surface of the basal callus, and is provided with definite, apically rounded walls. Inside the walls a gelatinous, non-viscous, shiny exudate is produced, which is spread through a longitudinal groove to the apex of the lip, where it apparently dries, becoming matte, in two to three days (Fig. 4). In most species, there is a pair of intramarginal low lamellae, typically undulate on the upper margin.
Taxonomy. The first species belonging to Echinosepala was described in 1855 as Pleurothallis aspasicensis from Colombia (Reichenbach 1855), followed by Pleurothallis uncinata Fawcett (1895), from a Jamaican collection. Both species have been treated as taxa with broad geographic distribution: E. aspasicensis ranging from Costa Rica to Bolivia, the Guyanas, and Brazil, and E. uncinata recorded from the West Indies and Central America (Luer 1992). The correct application of both names is nonetheless problematic.

The type specimen of E. aspasicensis at Kew (Wagener 618!) just consists of a crumpled flower from which the lip is missing, and no vegetative material has been conserved. Reichenbach (1855) described the lip as ligulate, attenuate at the retuse apex, provided with two small falcate lobes at the base, with a transverse keel on the disc and two small 


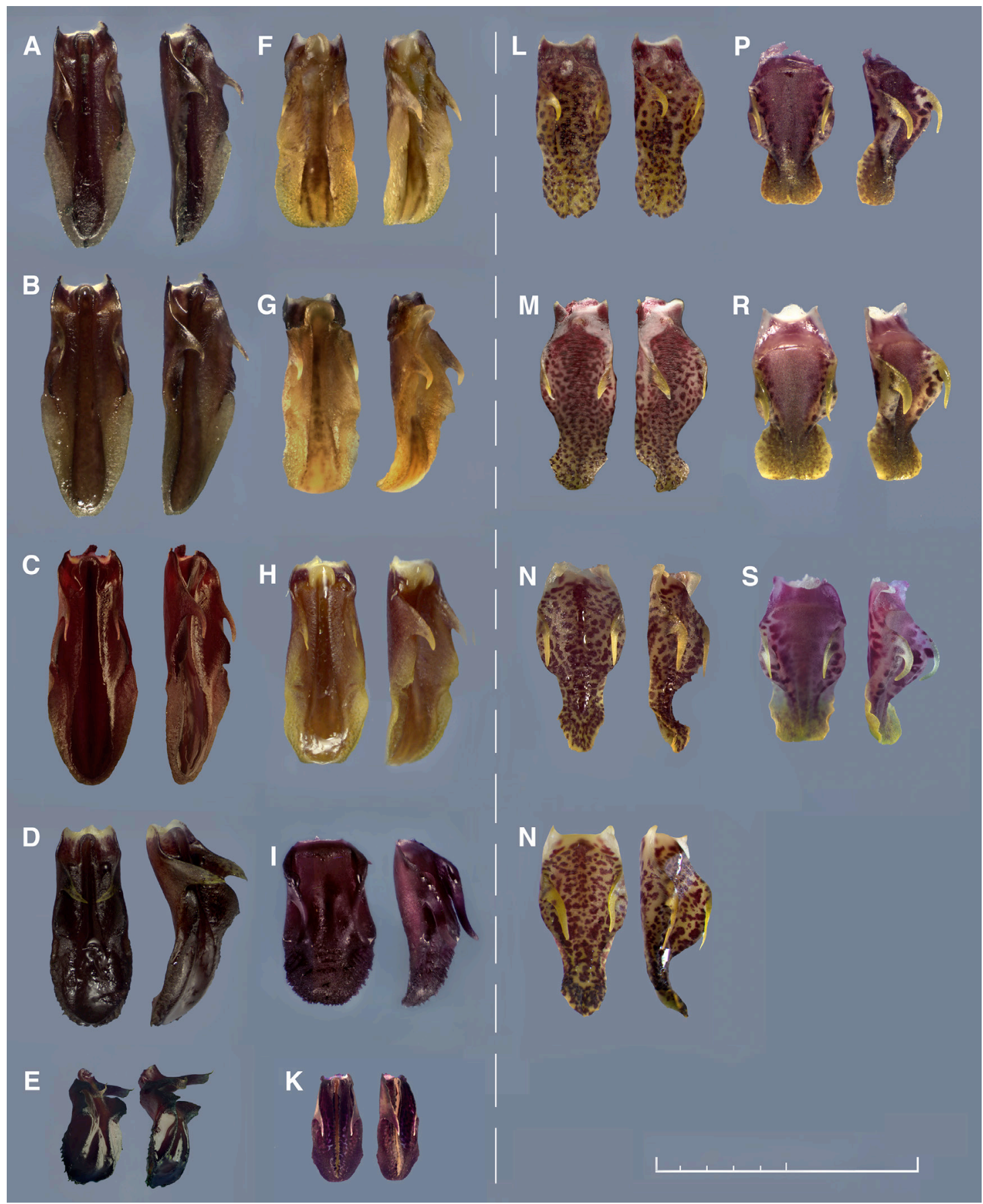

Figure 4. Labella of Echinosepala species. On the left of the dashed line (A-K), labella with pseudo-glenion. On the right of dashed line (L-S), species without pseudo-glenion. A-C, E. aspasicensis (Bogarín 1945, JBL-27660, JBL-02078, respectively). D, E. expolita (Bogarin 1871). E, E. pan (Bogarin 10274). F-H, E. longipedunculata (Bogarin 3863, Bogarin 5449, Karremans 4494, respectively). I, E. stonei (Bogarín 7191). K, E. tomentosa (Bogarin 5622). L-N, E. sempergemmata (Bogarin 4601, Karremans 3199, Bogarín 4678, respectively). P-S, E. uncinata (Bogarin 5855 , Bogarin 5871, Whitten 2153, respectively). Scale bar $=1 \mathrm{~cm}$. All the vouchers at JBL. Photographs by F. Pupulin. 


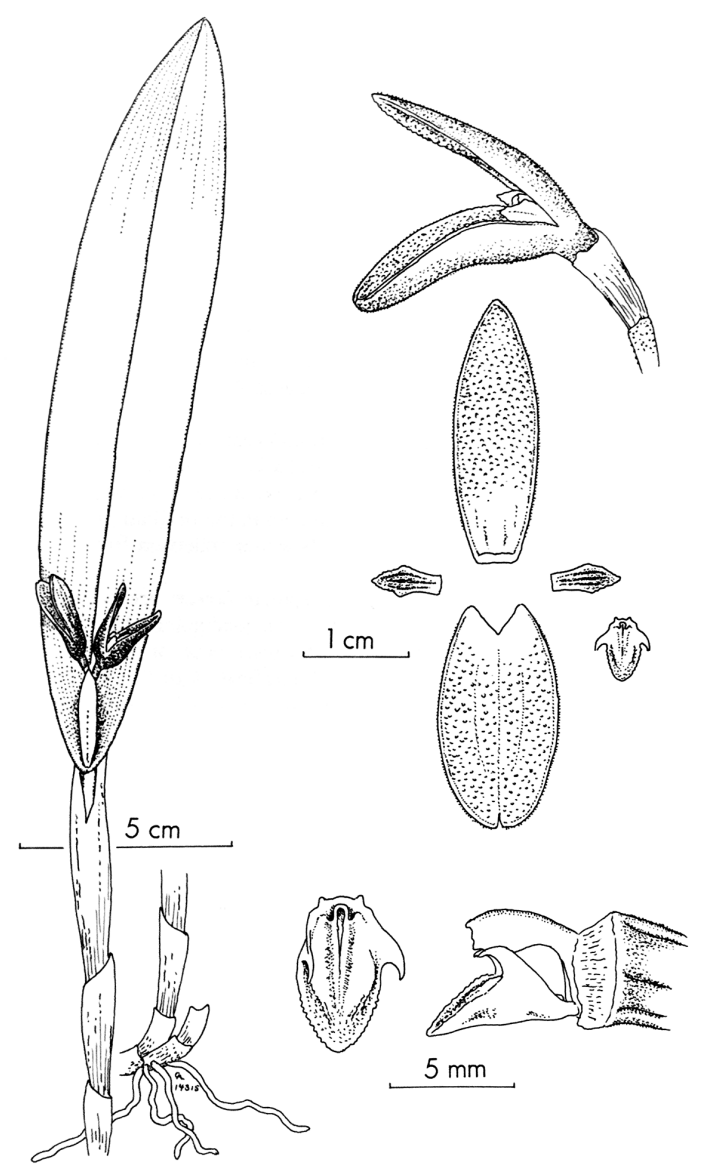

Figure 5. A Colombian specimen of Echinosepala (as Myoxanthus) aspasicensis (Luer 14315), from Luer 1992 (pl. 45). Courtesy of the Missouri Botanical Garden.

keels in front of the lateral lobes, running parallel to the margins of the midlobe; he did not mention a horseshoe-shaped, concave structure sitting on the basal callus that we refer to in this paper as pseudoglenion. The only modern documentation of a Colombian plant that we are aware of is that illustrated by Luer (1992: pl. 45), but this specimen was collected some 200 kilometers south of the type locality, along the western slopes of the Eastern Cordillera. Luer's specimen shows a plant with two bilabiate flowers, with a short, broad, elliptic lip (Fig. 5), quite distinct from Costa Rican populations treated under E. aspasicensis (Luer 2003 [under Pleurothallis], Pridgeon 2005b), which typically present a single flower and a narrow, elliptic-oblong, elongate lip. Only an effort to document the morphological and

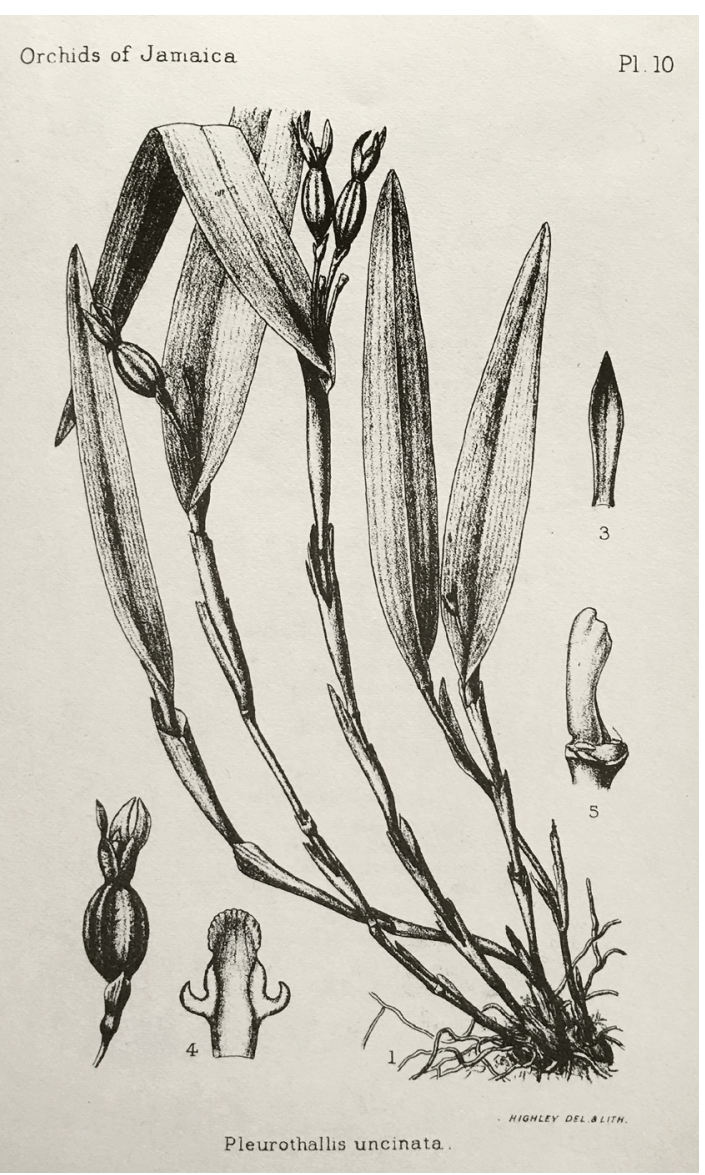

FIgURE 6. Echinosepala (as Pleurothallis) uncinata from Jamaica, from Fawcett \& Rendle 1910 (pl. 10).

genetic variation of Echinosepala species at the type locality, near Aspasica in Colombia, could resolve the identity of the true E. aspasicensis, allowing the proper identification of similar taxa across the alleged distribution of the species.

The type specimen of E. uncinata (Harris s.n., K 584080!), on the other hand, shows a large plant, with ramicauls almost $20 \mathrm{~cm}$ long, which contrast with populations from Costa Rica that usually have ramicauls only $10-14 \mathrm{~cm}$ in length, and in size approaches instead Costa Rican specimens of $E$. sempergemmata. The floral parts of the type specimen consist of a floral bud and a fruit, and also the drawing of the species prepared by Percy Highley (1856-1929) for Fawcett and Rendle's treatment of Orchidaceae for Flora of Jamaica (Fawcett \& Rendle 1910) depicts a 
large plant with only pollinated flowers (Fig. 6). These are described as "scabrous" (Fawcett 1895) or "rough on inner and outer sides, tomentose on outer side" (Fawcett \& Rendle 1910), a character that contrasts with Costa Rican populations treated under E. uncinata (which have glabrous flowers), and agrees instead with E. sempergemmata, with which we strongly suspect it is conspecific.

In preparation of a systematic treatment of Echinosepala for the flora of Costa Rica, we confidently describe in this paper two new species in the genus, as they cannot be confused with any of the previously published names. The Costa Rican Pleurothallis alexandrae Schltr., which is obviously a species of Echinosepala, belongs to the group of species that present a broad and smooth callus at the base of the lip, while both the new taxa proposed here have a basal pseudo-glenion. Of the new taxa, one is close to E. pan, a species that otherwise has no close relatives. The other is close to A. aspasicensis sensu lato, but it has a very long peduncle and a truncate lip that were not previously recorded in any other species of the genus.

Materials and methods. Plants used for this study were collected around the country and brought to Lankester Botanical Garden (JBL) for cultivation and subsequent documentation. Whenever possible, type localities and critical localities from where rare and/or unique species records were previously reported were visited for plant collecting and subsequent study. At least five specimens per morphospecies were collected at any given locality whenever possible. Field notes were taken during collections, including GPS and political data, elevation, ecological zones and main types of vegetation. Plants were cultivated at JBL, recording phenological data.

Morphological analysis.- We studied and documented over 150 individuals within this group, belonging to virtually all the morphospecies known for the country (Pupulin et al., in prep.). Notes on floral ecology were taken through direct observation of the plants under the semi-artificial conditions of open greenhouses. Several plants in this group were documented at flowering with high-resolution images of the flower provided with a scale, often including views of the whole plant and floral details with relative scales. Photographs were taken with Nikon cameras (D5200, D7100, D810) fitted with macro

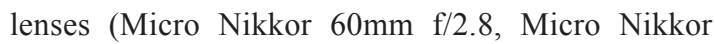
$105 \mathrm{~mm}$ AF f/2.8, Micro Nikkor 105mm G AF-S/ ED-IF/VR f/2.8, Sigma Macro 105mm AF/EX/DG/ OS/HSMS f/2.8). Floral details were captured with a Micro-Nikkor 60mm f.2.8 mounted on a Nikon PB6 bellow or on extension tubes, and/or with microscopes (Leica macroscope Z16APO and Leica dissecting stereo microscopes MZ9.5 and M60) fitted with Leica DFC420 Digital Color Microscope cameras. Comparative plates of flowers and/or relevant floral details were prepared with Adobe ${ }^{\circledR}$ Photoshop 5.0 and 6.0. Drawings of flowers and floral details were prepared using dissecting stereo microscopes Leica MZ9.5 and M60, fitted with Leica ApoPlanar lenses and with drawing tubes. One or more vouchers for each specimen were conserved in the liquid collection of JBL. Individual plants intended for the description of new species were also preserved as dried specimens to be deposited in the herbaria of the National Museum of Costa Rica (CR) and the University of Costa Rica (USJ). Measurements were mostly taken under a dissecting stereoscope, or with the aid of the electronic scale bars inserted in the high definition images of the floral details. The major herbaria of the country, as well as relevant herbaria that allow digital access to their collections, were reviewed to study specimens of the taxa intended for this study, and specimens annotated when required.

DNA extraction and sequencing.- The selection of the material was based on availability and interspecific variability. Whenever possible species are represented by more than a single accession (Table 1). Vouchers of the specimens are kept in the liquid collections at JBL or L, unless specified otherwise. Fresh leaf and flower cuttings of about $1 \mathrm{~cm}^{2}$ were obtained from the selected individuals of each species. Each individual sample was put into a polypropylene bag with silica gel to dry for about a week after which the silica was removed and new dry silica was added. Twenty-mg samples were pulverized in liquid nitrogen by shaking them in a Retsch MM 300 shaker for 5 min using three bullets. Extraction was performed following the DNEasy extraction 
TABLE 1. List of accessions used in the phylogenetic analyses here presented. The vouchers, NCBI GenBank accession number and source are given.

\begin{tabular}{|c|c|c|c|}
\hline Taxon & Voucher & ITS & Source \\
\hline Arpophyllum giganteum Hartw. ex Lindl. & None & AF266742 & Pridgeon et al 2001 \\
\hline Barbosella cucullata (LIndl.) Schltr. & Chase 1334 & AF262815 & Pridgeon et al 2001 \\
\hline Barbosella handroi Hoehne & Chase 1436 & AF262813 & Pridgeon et al 2001 \\
\hline Barbosella miersii (Lindl.) Schltr. & Chase 6809 & AF262816 & Pridgeon et al 2001 \\
\hline Barbosella orbicularis Luer & Chase 1444 & AF262814 & Pridgeon et al 2001 \\
\hline Dresslerella elvallensis Luer & Chase 1279 & AF262901 & Pridgeon et al 2001 \\
\hline Dresslerella hirsutissima (C.Schweinf.) Luer & Chase 1306 & AF262902 & Pridgeon et al 2001 \\
\hline Dresslerella pertusa (Dressler) Luer & Chase 1326 & AF262903 & Pridgeon et al 2001 \\
\hline Echinosepala aspasicensis (Rchb.f.) Pridgeon \& M.W.Chase (1) & Bogarín 8211 & KP012468 & This Study \\
\hline Echinosepala aspasicensis (Rchb.f.) Pridgeon \& M.W.Chase (2) & Bogarín 1945 & KP012469 & This Study \\
\hline Echinosepala aspasicensis (Rchb.f.) Pridgeon \& M.W.Chase (3) & Chase 971 & AF262905 & Pridgeon et al 2001 \\
\hline Echinosepala expolita & Bogarín 1871 & KP012479 & This Study \\
\hline Echinosepala longipedunculata (1) & Bogarín 5449a & KP012480 & This Study \\
\hline Echinosepala longipedunculata (2) & Bogarín 5449b & KP012481 & This Study \\
\hline Echinosepala pan (Luer) Pridgeon \& M.W.Chase (2) & Bogarín 1913 & KP012471 & This Study \\
\hline Echinosepala sempergemmata (Luer) Pridgeon \& M.W.Chase (1) & Bogarín 7137 & KP012472 & This Study \\
\hline Echinosepala sempergemmata (Luer) Pridgeon \& M.W.Chase (2) & Bogarín 5775 & KP012473 & This Study \\
\hline Echinosepala sempergemmata (Luer) Pridgeon \& M.W.Chase (3) & Bogarín 10717 & KP012474 & This Study \\
\hline Echinosepala stonei (Luer) Pridgeon \& M.W.Chase (1) & Bogarín 5777a & KP012482 & This Study \\
\hline Echinosepala stonei (Luer) Pridgeon \& M.W.Chase (2) & Bogarín 5777b & KP012483 & This Study \\
\hline Echinosepala stonei (Luer) Pridgeon \& M.W.Chase (3) & Bogarín 7190 & KP012484 & This Study \\
\hline Echinosepala tomentosa (Luer) Pridgeon \& M.W.Chase & Bogarín 5622 & KP012485 & This Study \\
\hline Echinosepala uncinata (Fawc.) Pridgeon \& M.W.Chase (1) & Chase 1321 & AF262904 & Pridgeon et al 2001 \\
\hline Echinosepala uncinata (Fawc.) Pridgeon \& M.W.Chase (2) & Bogarín 5871b & KP012487 & This Study \\
\hline Echinosepala vittata (Pupulin \& M.A.Blanco) Luer & Blanco 1324 & KP012487 & This Study \\
\hline Myoxanthus exasperatus (Lindl.) Luer & Chase 1323 & AF262882 & Pridgeon et al 2001 \\
\hline Myoxanthus punctatus (Barb.Rodr.) Luer & Chase 1324 & AF262885 & Pridgeon et al 2001 \\
\hline Myoxanthus serripetalus (C.Schweinf.) Luer & Chase 1329 & AF262883 & Pridgeon et al 2001 \\
\hline Pleurothallopsis nemorosa (Barb.Rodr.) Porto \& Brade & Bock s.n. & AF291099 & Pridgeon et al 2001 \\
\hline Pleurothallopsis striata (Luer \& R.Escobar) Pridgeon \& & Chase 1103 & AF262910 & Pridgeon et al 2001 \\
\hline Restrepia antennifera Kunth & Chase 982 & AF262906 & Pridgeon et al 2001 \\
\hline Restrepia aristulifera Garay \& Dunst. & Chase 1109 & AF262907 & Pridgeon et al 2001 \\
\hline Restrepia muscifera (Lindl.) Rchb.f. ex. Lindl. & Chase 308 & AF262908 & Pridgeon et al 2001 \\
\hline Restrepiella ophiocephala (Lindl.) Garay \& Dunst. & Chase 291 & AF262909 & Pridgeon et al 2001 \\
\hline
\end{tabular}

protocol (QIAGEN). DNA concentration for each sample was adjusted to $10 \mu \mathrm{mol} / \mathrm{l}$ using a Nano Drop Spectrophotometer (ND 1000). The nuclear ribosomal internal transcribed spacer (ITS) region was amplified using the methods and primers 17SE (ACGAATTCATGGTCCGGTGAAGTGTTCG) and 26SE(TAGAATTCCCCGGTTCGCTCGCCGTTAC) for sequencing and amplification, as described by Sun et al. (1994). Amplification was done by preparing each sample with a PCR mix composed of DTB, dNTPs, both primers (four in the case of ITS), Dream Taq, water, and the extracted DNA. Samples were amplified in a MJ Research PTC-200 Pelthier Thermal Cycler, using a temperature profile of $94^{\circ} \mathrm{C} / 5$ $\mathrm{min}$, followed by 34 cycles of $94^{\circ} \mathrm{C} / 30 \mathrm{~s}, 55^{\circ} \mathrm{C} / 30 \mathrm{~s}$, and $72^{\circ} \mathrm{C} / 2 \mathrm{~min}$, and finally $72^{\circ} \mathrm{C} / 10 \mathrm{~min}$. To prepare 
for sequencing, a DETT kit was used according to the manufacturer's specifications (GE Healthcare). Each sample had two mega-mixes, one for the F-primer and another for the R-primer (four for ITS), and were cycle-sequenced using a standard thermo-profile of $94^{\circ} \mathrm{C} / 20 \mathrm{~s}, 50^{\circ} \mathrm{C} / 15 \mathrm{~s}$, and $60^{\circ} \mathrm{C} / 1 \mathrm{~min}$, repeated 25 times. Products were analyzed on an ABI 9600 DNA analyzer.

Building the data sets. - The STADEN (Staden et al. 2003) package was used for editing the sequences. Where more than one base pair was equally probable, the Unicode nomenclature (IUPAC) was used. In a few cases the two traces for one sample were too short and there was no overlap so Pregap was unable to build a contig. In order to keep the information, both sequences were merged by filling in missing positions with N's. Sequences were aligned manually in Mesquite v2.72 (Maddison \& Maddison 2007). The ends of each data set were trimmed to eliminate possible erroneous data, and gaps at the ends of sequences were regarded as missing data (filled in with $\mathrm{N}^{\prime} \mathrm{s}$ ). Each indel and possible informative sites were re-checked by going back to the original traces. After the alignments had been edited, additional sequences were obtained from GenBank, the latter using nBLAST. Arpophyllum giganteum Hartw. ex Lindl. AF266742 (ITS) was used as outgroup in all cases, as it is suggested to be the furthest related of all included species (Pridgeon et al. 2001).

Phylogenetic analysis. - Bayesian analyses methods were preferred over Parsimony and Maximum Likelihood because they were found to explain the data better and have overall higher support and resolution. The Bayesian Evolutionary Analysis Sampling Trees (BEAST; Drummond \& Rambaut 2007) was used to analyze the ITS matrix. Substitution and clock models were unlinked. GTR $+\Gamma$ model, estimated frequencies, and 8 categories were used. The Lognormal relaxed clock model was used. The tree prior was speciation - Yule birth, while the number of generations was set to $30,000,000$. The first $20 \%$ of the resulting trees were used as burnin. Trees were visualized in FigTree v.1.3.1 (Rambaut 2009). Posterior probability (PP) values were added to the branches of the trees using the labeling option. Branches were reordered for better visualization.

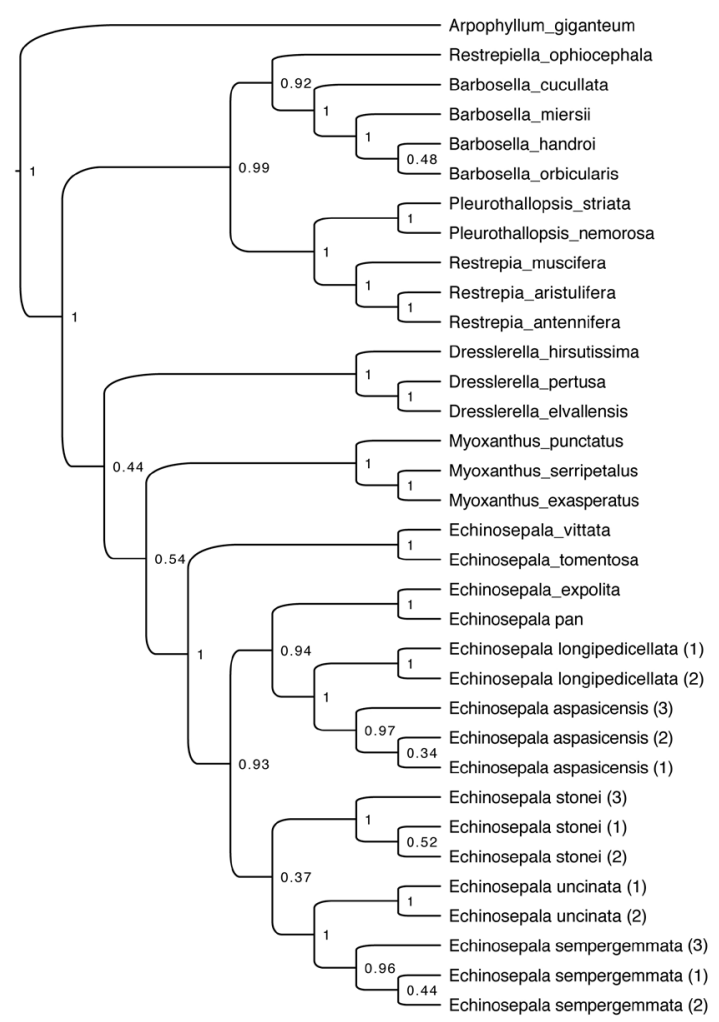

FIGURE 7. Phylogenetic relationship amongst the species of Echinosepala. The trees were produced with an analysis of ITS datasets, using BEAST v1.8.0. Parameters were set to preset, except for substitution model GTR with 8 categories, clock model uncorrelated lognormal (ITS), tree prior Yule process, and number of generations $30,000,000$. The resulting trees were combined using TreeAnnotator v1.6.0., with the first $20 \%$ of the trees were used as burnin. Node values are posterior probabilities. Tree edited using FigTree v.1.3.1.

Results. Species of Echinosepala form a highly supported clade, consecutively sister to Myoxanthus, Dresslerella, and a clade grouping species of Pleurothallopsis and Restrepia, and species of Restrepiella and Barbosella on two branches (Fig. 7). Within Echinosepala, E. aspasicensis and E. longipedunculata are highly supported as sister species, and in turn they are well supported as sister to E. pan and E. expolita. The latter two species cannot be differentiated by their ITS sequences.

Echinosepala sempergemmata and E. uncinata form a well-supported group, which in turn is sister (with low support) to E. stonei. In our analysis, the 
phylogenetic position of E. stonei is not resolved, but the species is surely not closely related to the group of E. expolita/E.pan. In order to better resolve the relationships between the derived species with a smooth lip callus and no pseudo-glenion, the analysis would surely benefit by including a sample of $E$. lappiformis, which is very close to $E$. stonei in both vegetative and flower morphology.

Echinosepala tomentosa and E. vittata, both characterized by miniature plant habits and flowers, are sister to all the other species in a highly supported group.

\section{New TaXa}

\section{Echinosepala expolita Pupulin \& Belfort, sp. nov.}

TYPE: Costa Rica. Alajuela: San Ramón, Piedades, Piedades Norte, road to Bajo La Paz, ca. km 3, along the Río San Pedro, 1008'58.7'N 84³4'03.3”W, 1300 $\mathrm{m}$, premontane wet forest, secondary and remnants of primary vegetation, 19 February 2008 F. Pupulin 7030, R.L. Dressler \& A. P. Karremans (holotype, JBL!; isotypes, JBL!). Fig. 1C, 2, 3B, 4D, 8-13.

Species Echinosepala pan (Luer) Luer similis, caulum vaginis glabris paulo inflatis, foliis ligulatolanceolatis multo latioribus, ovario lanato-hirsuto, floribus multo majoribus indumento abaxialis sepalorum tomentoso munitis praecipue differt.

Epiphytic, caespitose, erect herb up to $30 \mathrm{~cm}$ tall. Roots coarse, flexuous, $1.5-2.0 \mathrm{~mm}$ in diameter. Ramicauls stout, erect, terete, thicker in the distal portion, 6.0-12.5 $\mathrm{cm}$ long, homoblastic, composed by 5 nodes different in length, completely enclosed by $3-5$ papyraceous, tubular, ancipitous, apically loose, obliquely truncate, whitish, glabrous, inflated sheaths, increasing in size toward the upper one, $1.4-7.7 \times 0.2-0.8 \mathrm{~cm}$, the oldest ones breaking longitudinally and eventually disintegrating with age. Leaf erect, coriaceous, linear-elliptic, subacute, minutely emarginate at the apex, $1.8-2.4 \times 16.2-27.0$ $\mathrm{cm}$, with the midvein strongly protruding abaxially. Inflorescence a fascicle of single, successive flowers produced facultatively at the apex and the base of the ramicaul at once; the peduncle terete-subclavate, erect, glabrous, 1.8-2.5 mm long. Floral bract papyraceous, loose, obliquely truncate-subobtuse, $1.8-2.4 \mathrm{~cm}$ long.
Pedicel terete-subclavate, $1.8-2.5 \mathrm{~cm}$ long; ovary lanate-hirsute, completely covered by the bract, linear-subclavate, $3 \mathrm{~mm}$ long. Flowers bilabiate, with temporal activity, fully opening during the morning and closing in late afternoon; the sepals light greenish yellow, with the adaxial basal half mottled purple-red and the distal half with pointed verrucae becoming denser toward the apex, abaxially flushed with purple and densely warty-pubescent; the petals yellow, blotched with purple-red, sparsely verrucose; the lip dark purple, apically covered with a translucent wax in fresh flowers. Dorsal sepal elliptic-oblong with apex subacute, $1.9-2.0 \times 0.4-0.9 \mathrm{~cm}, 7$ - to 9 -veined, a semitransparent base forming a window under the dark purple-red blotches, tomentose abaxially, adaxially provided with spiny warts in the apical half. Lateral sepals connate into an elliptic, abaxially tomentose synsepal, 1.6-1.7 × 0.4-1.0 cm, each sepal 5-veined, the apices free about $6 \mathrm{~mm}$, subacute-rounded, with pointed-spiny warts in the distal half. Petals fleshy, rhombic, obliquely asymmetric, acute, 6-7 × 1-3 $\mathrm{mm}, 3$-veined, apically provided with spiny warts. Lip 3-lobed, narrowly oblong-obovate from a small, rounded, thin, dark purple claw, $7.5 \times 2.2 \mathrm{~mm}(5.0$ $\mathrm{mm}$ across the lateral lobes expanded), the base subtruncate; lateral lobes basal, erect, narrowly linearsubuncinate, antrorse; the apical lobe elliptic-truncate, with irregular margins, provided with a pair of intramarginal, thin keels running from the disc, inside the lateral lobes, to the middle of the midlobe blade, thickened at the apex into a cushion-like, elliptic, low pad; the disc with an erect, narrow callus arising above the base the lip, covered on the top by a horseshoeshaped, channeled pseudo-glenion, from which a gelatinous exudate is produced, extending in front into a low groove flushing into the apical pad. Column straight to subarcuate, semiterete, 4.4-5.5 mm long, provided with long, narrow, subrectangular wings above the middle, the foot ca. $2.3 \mathrm{~mm}$ long. Anther cap globose, cucullate, with conspicuous, stiff hairs on the upper margin, 2-celled. Pollinia 2, obovoid, flattened, on a short bilobed caudicle. Capsule not seen.

Paratype: Costa Rica. Alajuela: San Ramón, Ángeles, Reserva Biológica Alberto M. Brenes, 10¹3’06” N 84³6’11” W, $850 \mathrm{~m}$, bosque muy húmedo tropical transición a premontano, sobre el Sendero La Catarata, 


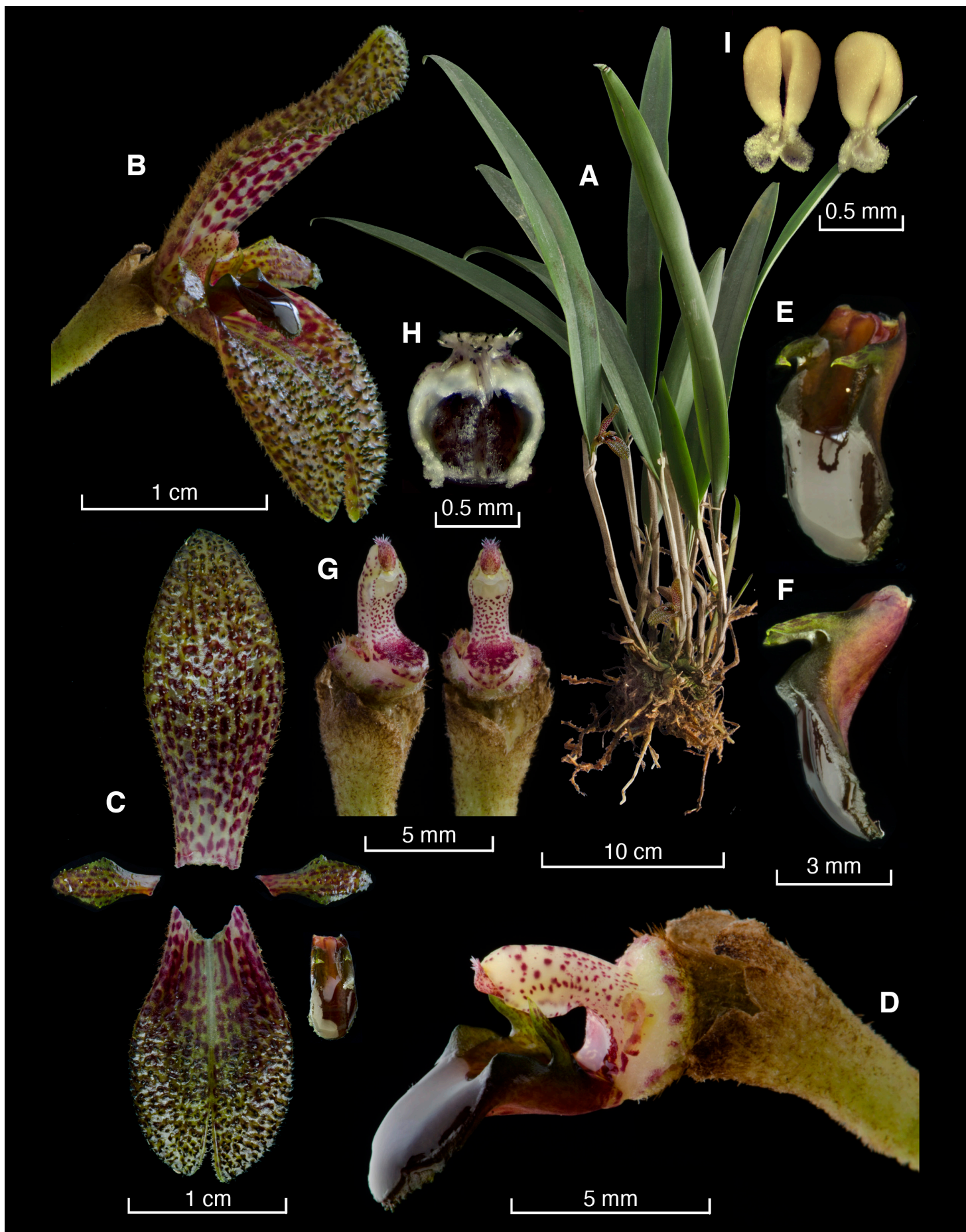

Figure 8. Lankester Composite Digital Plate of Echinosepala expolita. A. habit. B, flower. C, dissected perianth. D, ovary, column and lip in lateral view. E-F, labellum, three-quarters and lateral views. G, column, three-quarters and ventral views. H, anther cap. I, pollinarium, dorsal and ventral views. Based on the holotype. Photographs and digital composite by F. Pupulin. 


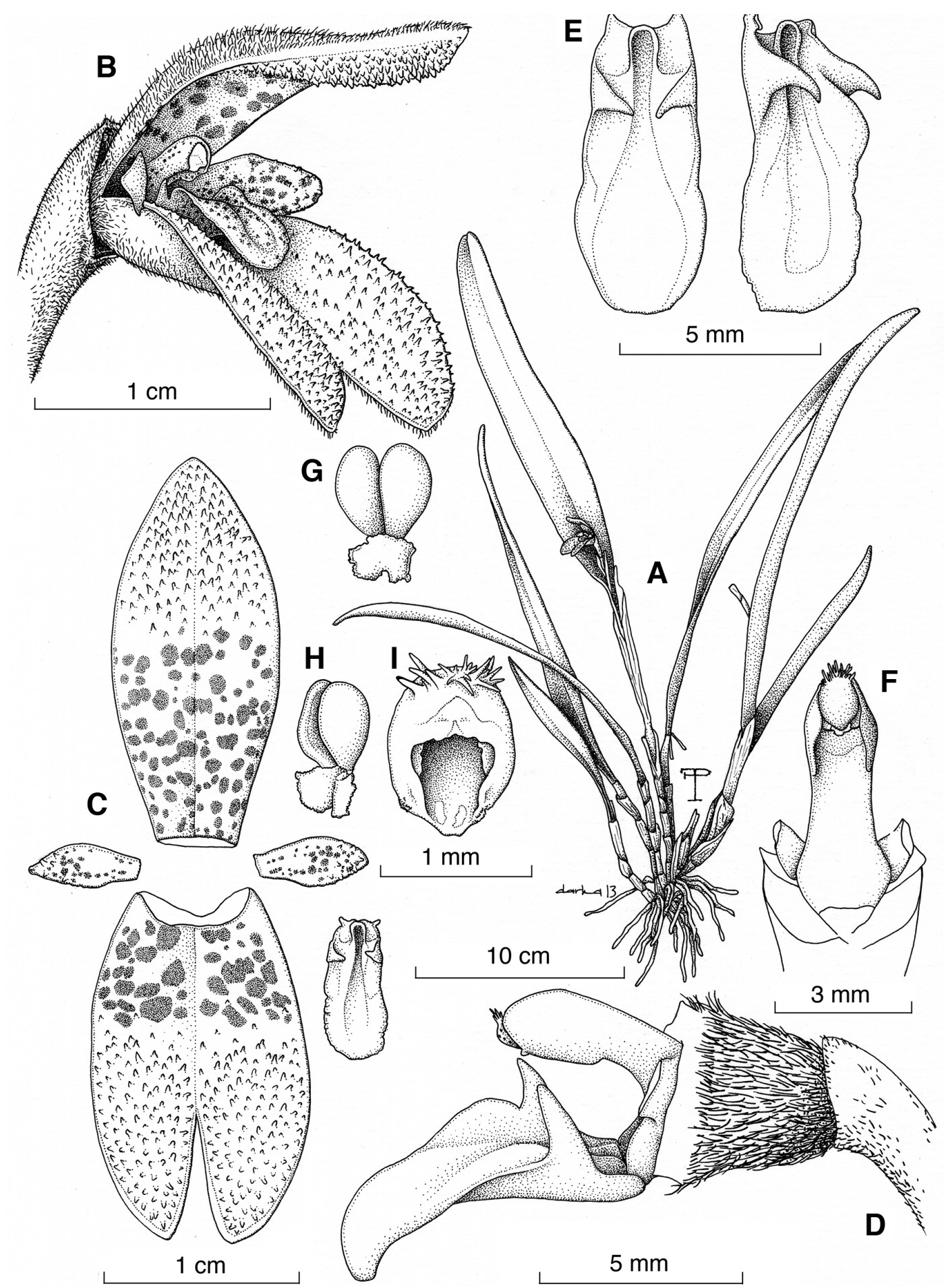

Figure 9. Echinosepala expolita Pupulin \& Belfort. A. habit. B, flower. C, dissected perianth. D, ovary, column and lip in lateral view. E, labellum in ventral and three-quarters views. F, column, ventral view. G-H, pollinarium in dorsal and three-quarters views. I, anther cap. Based on the holotype. Drawing by F. Pupulin and D. Solano Ulate. 


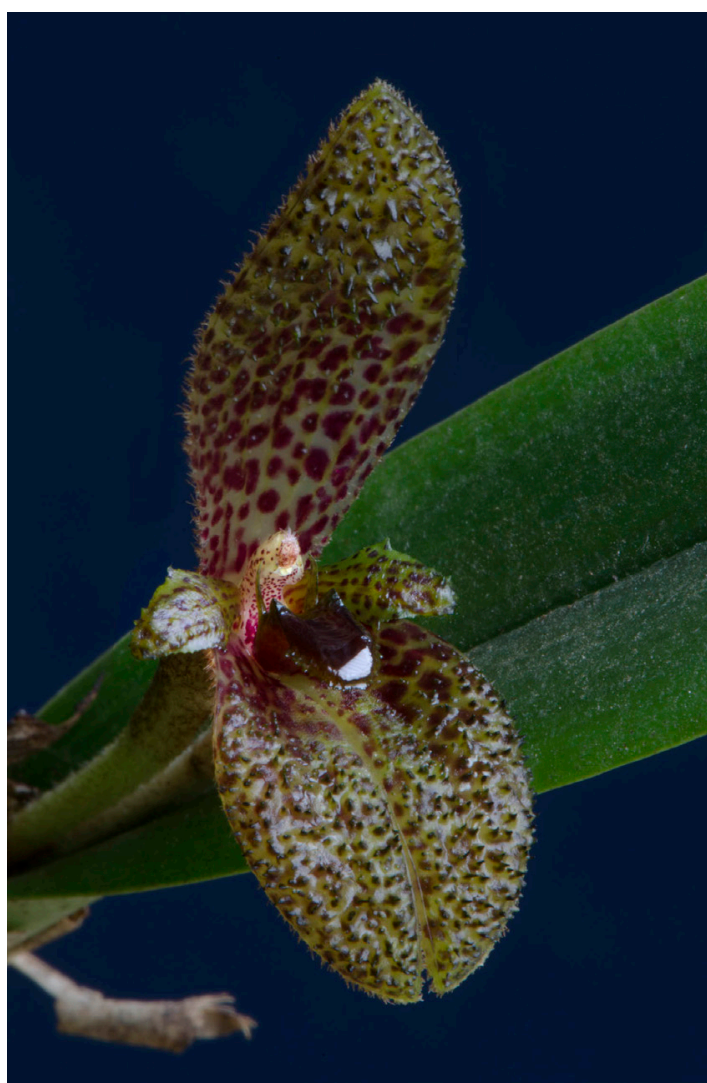

FIGURE 10. Flower of E. expolita, from the plant that served as the holotype. Photograph by F. Pupulin.

epífitas en borde de bosque secundario a orillas del Río San Lorencito, 24 setiembre 2005, D. Bogarín 1871 (USJ; isoparatype, JBL!) (Fig. 11).

Other material examined: Costa Rica. [Alajuela:] Piedades S. de San Ramón, Cerros de Laguna, 1190 m, 7 Nov.1922, A. M. Brenes 26219 (425 Herb. Brenes) (CR!, sterile); Alajuela: San Ramón, Cordillera de Tilarán, cerca a Balsa, ca. 12 km NE de San Ramón,

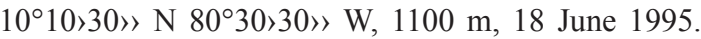
Epífita a $2 \mathrm{~m}$. Flores gris con manchas moradas y rayas blanco-hueso, suculentas. B. Hammel 19870 (CR!, sterile).

Eтymology: From the Latin expolitus, "shining, glossy," in allusion to the glossy apex of the lip in the fresh flowers with exudate.

Distribution: Only known from the Caribbean watershed of the Cordillera de Tilarán in central Costa Rica (Fig. 14).

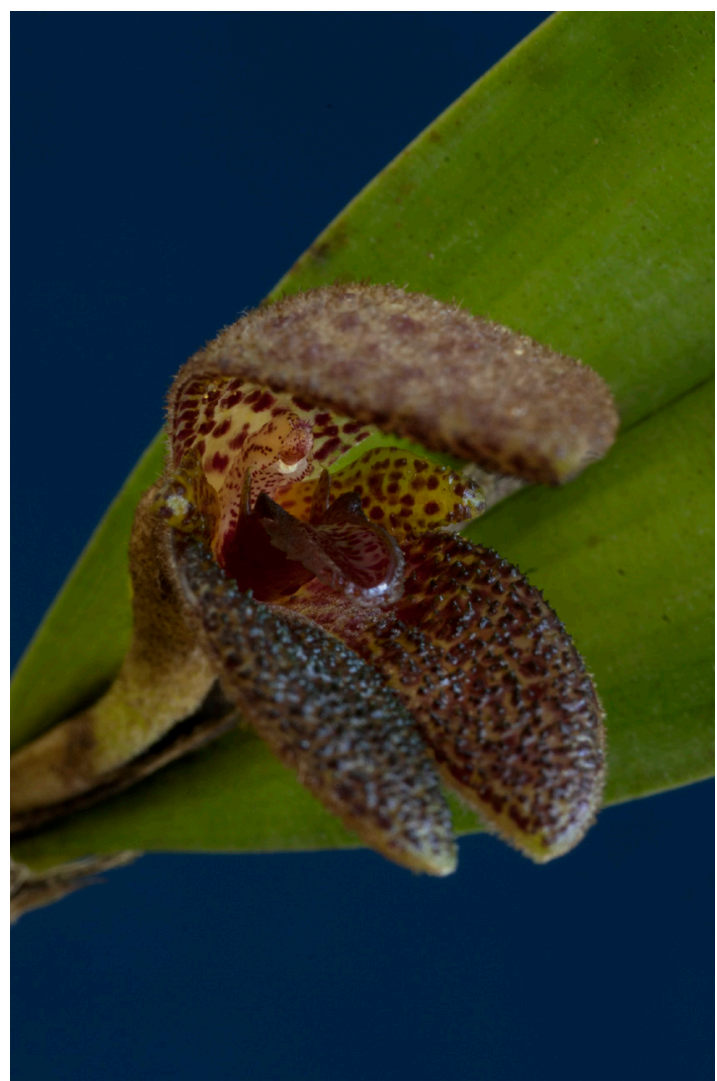

Figure 11. Flower of E. expolita (Bogarín 1871). Photograph by F. Pupulin.

Habitat AND ECOlOgy: Epiphytic in tropical, transition to premontane, and premontane wet forests along the Caribbean watershed of the Cordillera de Tilarán, at 800-1300 meters of elevation. Flowering has been recorded from March to June, and in November, but it is probable that the plants may flower at any time of the year. Each individual flower shows temporal activity, fully opening during the morning and closing in late afternoon. Flowers are usually almost to completely closed at night. During anthesis they emit a subtle but pungent smell, reminiscent of urea. The breakdown of urea to ammonia and carbon dioxide is known to lure insects, particularly fruit flies.

In plant architecture, E. expolita is similar to $E$. aspasicensis, with narrowly lanceolate leaves longer than the subtending ramicauls. The inflorescences, however, may be produced both at the apex of stem and from one of the lower nodes of the ramicaul, and may be exserted simultaneously (Fig. 2). The basal 


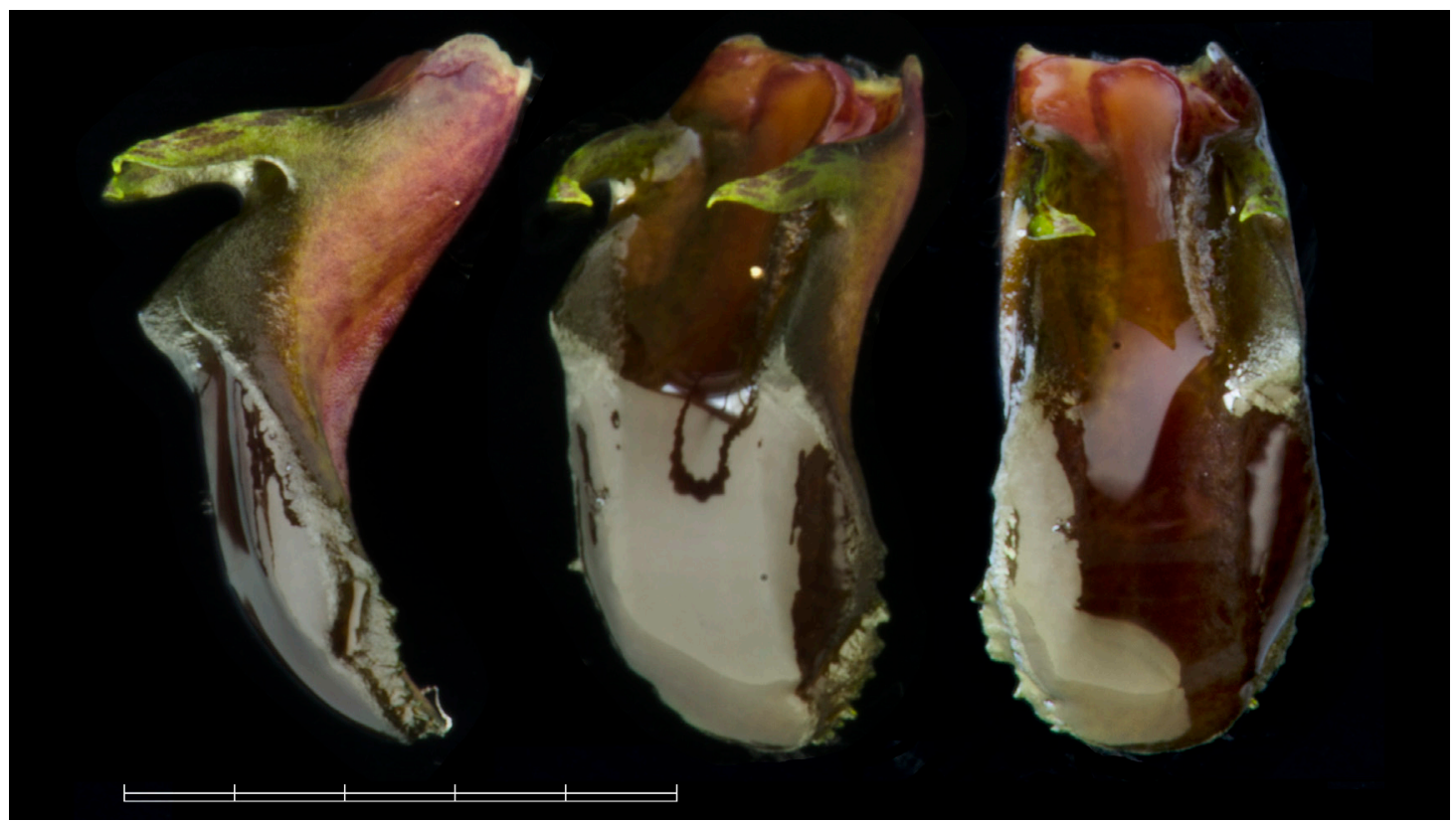

FIGURE 12. Three views of the labellum of E. expolita (Pupulin 7030) from a recently open flower. Note the shiny surface of the lip blade. Photographs by F. Pupulin.

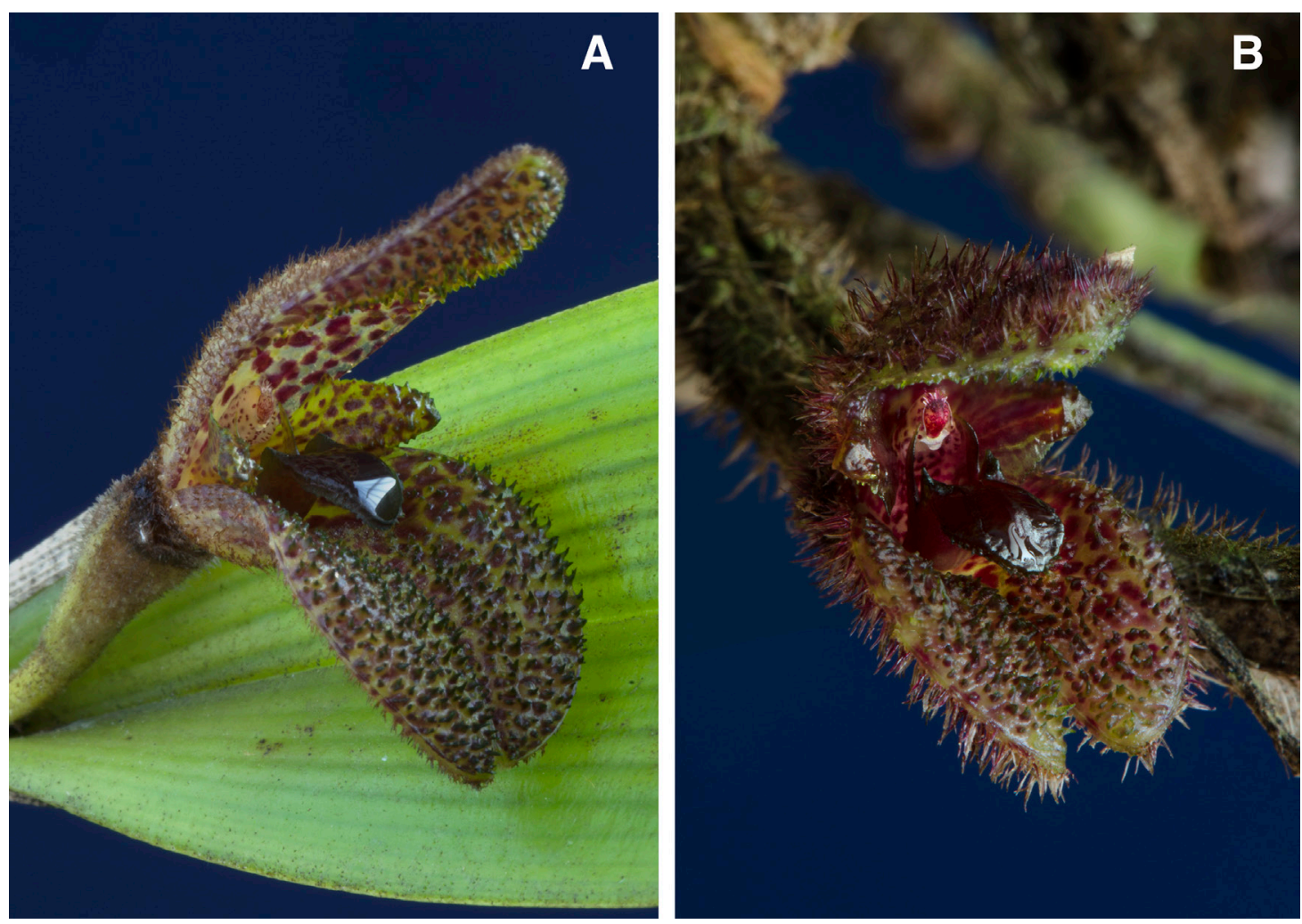

Figure 13. Comparison between the flowers of E. expolita (A) and E. pan (B). A, Pupulin 7030. B, Bogarín 10270. Vouchers at JBL. Photographs by F. Pupulin.

LANKESTERIANA 17(2). 2017. (C) Universidad de Costa Rica, 2017. 


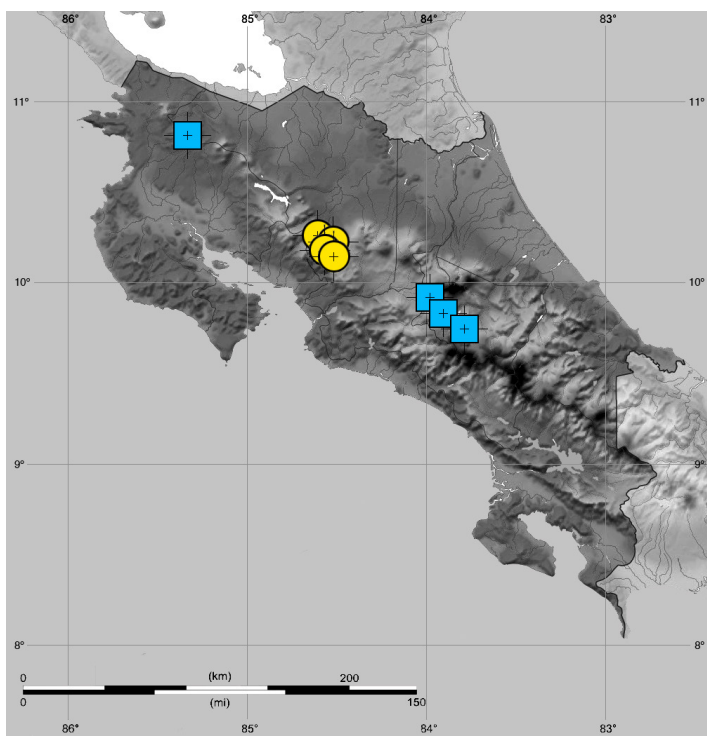

FIgURE 14. Distribution map of Echinosepala expolita (yellow circles) and E. longipedunculata (blue squares) in Costa Rica.

inflorescences are apparently not an ancestral condition in the group (Fig. 7). They may have originated on two independent occasions (in the clades of E. expolita $+E$. pan and in the clade of $E$. stonei). It is also possible that it evolved once, and one or two reversals to the ancestral state (apical inflorescence) occurred. Either scenario indicates that the species with basal inflorescences do not form a monophyletic group in Echinosepala.

Florally, E. expolita is close to E. pan, to which it appears related in the phylogenetic reconstruction presented (Fig. 7), and from which it can be distinguished by the glabrous, inflated sheaths that cover the stem (vs. hirsute, tight), the distinctly broader linear-elliptic leaves (vs. narrowly lanceolate), the lanate-hirsute ovary (vs. echinate), the much larger flower (sepals $>15 \mathrm{~mm}$ vs. $<10 \mathrm{~mm}$ long), and the tomentose abaxial indumentum of the sepals (vs, hirsute-echinate). At anthesis and in fresh flowers, the adaxial surface of the lip is covered with a translucent, waxy substance, which makes the lip shiny the basis for the specific epithet) and seemingly wet. This exudate, which appears to spread from the basal pseudo-glenion over the lip blade, is not sticky to touch, and it becomes progressively matte until the lip appears dry during the last days of anthesis.

The pseudo-glenion is apparently an ancestral character in Echinosepala, as it has been recorded in both the E. vittata $+E$. tomentosa clade, and in the clade including E. aspasicensis $+E$. longipedunculata and E. expolita $+E$. pan, and it was lost in the clade(s) of $E$. lappiformis $+E$. stonei and $E$. sempergemmata $+E$. uncinata.

It is noteworthy that despite the overwhelming differences in both vegetative architecture and flower morphology between the two species, E. expolita and $E$. pan have not acquired enough visible changes in the analyzed ITS region to be differentiated by genetic analysis. A very low nrITS sequence divergence in morphologically well distinguished but closely related species was also reported by Karremans et al. (2015) in genus Specklinia Lindl.

\section{Echinosepala longipedunculata Pupulin \& Karremans, sp. nov.}

Echinosepala aspasicensis (Rchb.f.) Pridgeon \& M.W.Chase plerumque similis, pedunculo pro genere longissimo, floribus viridiflavis (vs. brunneopurpureos), sepalorum indumento adaxiali verrucosotubercolato (vs. glabrum), labello aurantiace truncate breviore (vs. unum dimidiumque longiore, obtusum vel acutum, purpureum) recedit.

TYPE: COSTA RICA. Cartago: La Unión, San Rafael, Cerros de La Carpintera, Campamento Escuela Iztarú, 953'08.2”'N 8358'15.6”'W, $1778 \mathrm{~m}$, bosque húmedo premontano, epífitas en potreros arbolados, 30 octubre 2008, floreció en cultivo en el Jardín Botánico Lankester, 19 de junio 2012, D. Bogarín 5449, R.L. Dressler, R. Gómez, F. Pupulin, \& R. Trejos (holotype, JBL!). Fig. 4F-4H, 15, 16A, 17A.

Epiphytic, caespitose, erect herb up to 30 $\mathrm{cm}$ tall. Roots coarse, flexuous, $1.5-2.0 \mathrm{~mm}$ in diameter. Ramicauls stout, erect, terete, slightly complanate, thicker in the distal portion, $5.5-10 \mathrm{~cm}$ long, homoblastic, composed of 2 nodes differing in length, the lower one much shorter (to 1.5-2.2 $\mathrm{cm}$ long), completely enclosed by 3 papyraceous, tubular, ancipitous, apically loose, obliquely truncate, whitish sheaths, increasing in size toward the upper one, $2.0-6.5 \times 1.3-1.8 \mathrm{~cm}$, the oldest ones breaking longitudinally into long fibres and eventually disintegrating with age. Leaf erect, thickly coriaceous, linear-elliptic, subacute, minutely emarginate at apex, $15-18 \times 2.3-3.0 \mathrm{~cm}$, cuneate below into a conduplicate, sessile base, with the midvein strongly 


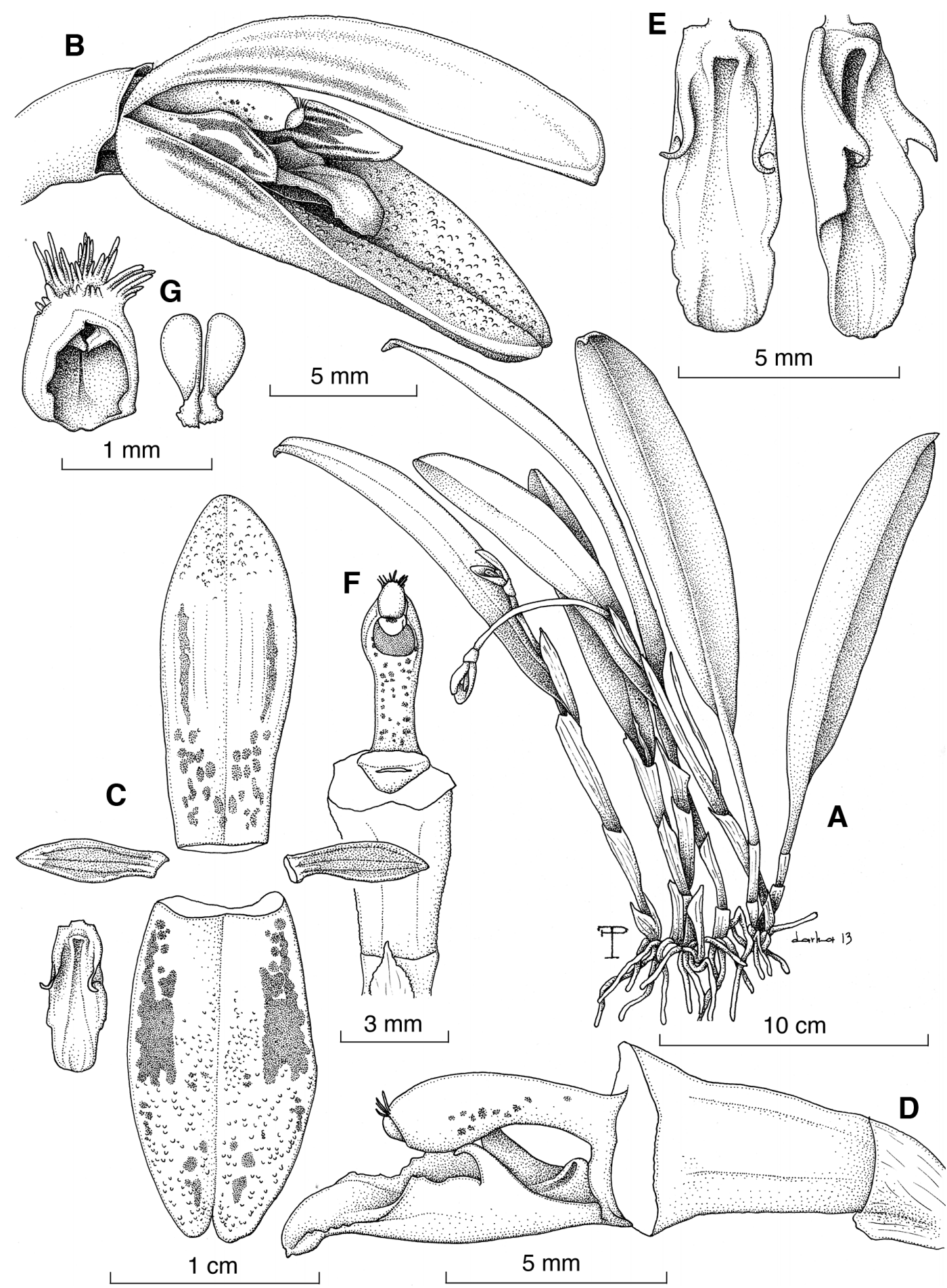

FiguRE 15. Echinosepala longipedunculata Pupulin \& Karremans. A. habit. B, flower. C, dissected perianth. D, ovary, column and lip in lateral view. E, labellum in ventral and three quarters views. F, column, ventral view. G, anther cap and pollinarium. Based on the holotype. Drawing by F. Pupulin and D. Solano Ulate. 
protruding abaxially and several lateral veins faintly visible on the adaxial blade. Inflorescence a fascicle of single, successive flowers at the apex of the ramicaul; the peduncle terete, suberect to gently arching, sparsely and minutely pubescent, $3-8 \mathrm{~cm}$ long, subtended by a papyraceous, whitish, ancipitous, obliquely truncate spathe $2.7-4.2 \mathrm{~cm}$ long. Floral bract papyraceous, loose, conduplicate, obliquely truncate-subobtuse, 7-10 $\mathrm{mm}$ long. Pedicel teretesubclavate, 4-5 mm long; ovary completely covered by the bract, linear-subclavate, $5 \mathrm{~mm}$ long, minutely scaberulous. Flowers bilabiate, with temporal activity, opening early in the morning and closing in the afternoon for three to four days; the sepals yellow, mottled dark purple on the inner side, flushed purple and densely scabrous to shortly pubescent externally, adaxially verrucose, the verrucae scattered at the base and becoming denser toward the apex, the petals yellow, heavily blotched with purple-red, the lip orange-yellow. Dorsal sepal oblong-obovate, obtuse, 19-21 × 6-7 mm, 7- to 9-veined. Lateral sepals connate into an elliptic synsepal, verruculose in the distal half, $17-19 \times 9-10 \mathrm{~mm}$, each sepal 5-veined, the free apices subacute-rounded. Petals fleshy, narrowly lanceolate, obliquely asymmetric, acute, $6-7 \times 1.5-1.8 \mathrm{~mm}$, 3-veined, the central vein thickened towards the base into a rounded keel. Lip 3-lobed, narrowly elliptic from a small, rectangular, thin, hyaline claw, $7 \times 2 \mathrm{~mm}(4.5 \mathrm{~mm}$ across the lateral lobes expanded), the base subtruncate; lateral lobes erect, narrowly uncinate, antrorse; the apical lobe rounded to subtruncate, thickened at the apex into a cushion-like, elliptic, low pad, provided with a pair of intramarginal, thin keels running inside the lateral lobes toward the disc; the disc with an erect, narrow callus arising above the base of the lip, the highest part covered by a horseshoe-shaped, channeled pseudo-glenion extending in front into a narrow groove flushing and expanding into the apical pad. Column straight to subarcuate, semiterete, 5.0 $5.5 \mathrm{~mm}$ long, provided with narrow, broadly rounded wings above the middle, the foot ca. $1.5 \mathrm{~mm}$ long. Anther cap globose, cucullate, with conspicuous, stiff hairs on the upper margin, 2-celled. Pollinia 2, obovoid, flattened, on a short, bilobed caudicle.

Paratypes: COSTA RICA. Cartago: Cartago, San Francisco, Muñeco, Finca Loma Verde y Jilguero,
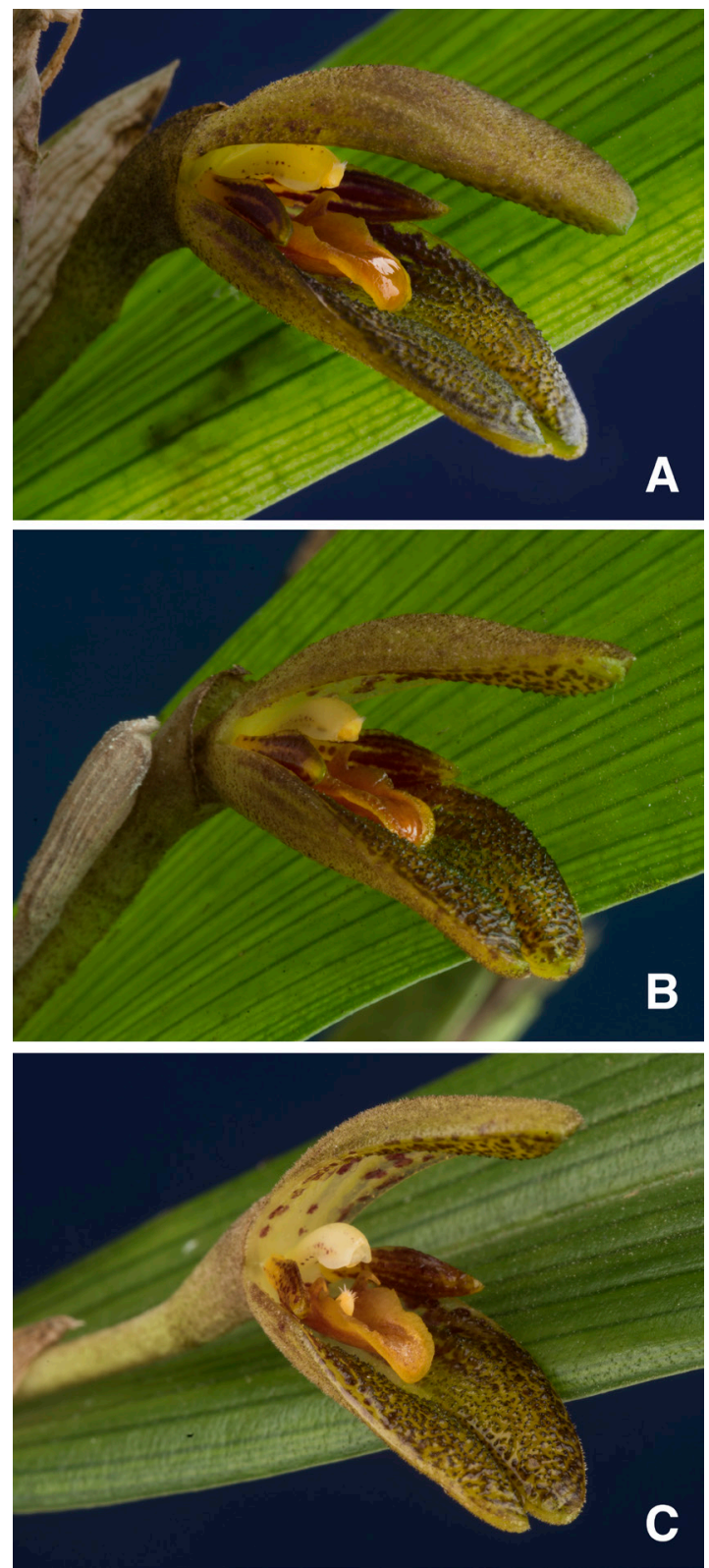

FigURE 16. Flowers of Echinosepala longipedunculata. A, Karremans 4944. B, Bogarin 5449. C, Chinchilla 2216. Vouchers at JBL. Photographs by F. Pupulin.

camino a Alto Belén, entre Río Sombrero y Quebrada Patarrá, 9०46'50.3”N 8354'21.1”W, 1430-1620 $\mathrm{m}$, bosque pluvial premontano, epífitas en bosque secundario y árboles en zonas abiertas, 23 mayo 2007, floreció en cultivo en el Jardín Botánico Lankester, 30 marzo 2013, D. Bogarín 3863, M. Bonilla, R. Gómez, Rafael Trejos \& J.D. Zúniga (JBL-spirit!); Cartago: 

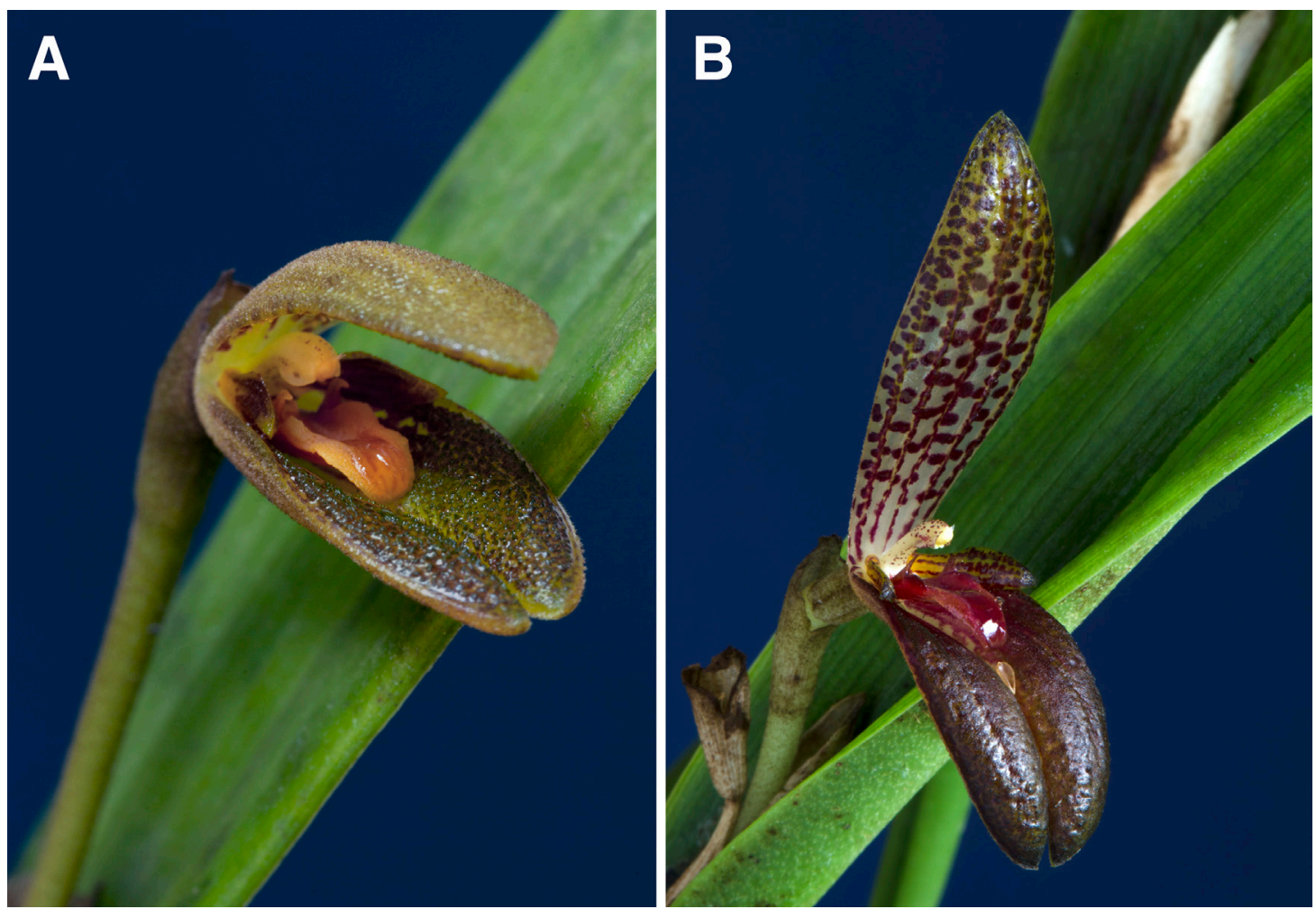

FIGURE 17. Comparison between the flowers of E. longipedunculata (A) and E. aspasicensis (B). A, Bogarín 5449. B, Karremans 4407 . Vouchers at JBL. Photographs by F. Pupulin.

Paraíso, Orosi, Tapantí, Parque Nacional Tapantí, unos $9 \mathrm{~km}$ después de la entrada principal del parque, 500 $\mathrm{m}$ después del puente superior sobre el río Grande de Orosi sobre la calle que va a la represa, $9^{\circ} 41^{\prime} 56.24^{\prime \prime} \mathrm{N}$ $83^{\circ} 46^{\prime} 53.12^{\prime} \mathrm{W}, 1570 \mathrm{~m}$, epífitas en árboles al lado de la calle principal, bosque pluvial premontano, $10 \mathrm{de}$ febrero 2012, floreció en cultivo en el Jardín Botánico Lankester, 9 marzo 2013, A.P. Karremans 4994 (JBLspirit!) (Fig. 16B). Guanacaste: Liberia, Liberia. Parque Nacional Rincón de la Vieja, sendero que recorre el sector Volcán Santa María, 1047>26.00»N, 85¹9»16.00”O, $1304 \mathrm{~m}$, bosque húmedo montano bajo, epífita, 24 Jan. 2015, flowered in cultivation at Lankester Botanical Garden, 29 Nov. 2016, I. Chinchilla 2216, R. Espinoza, C. Moraga, A. Guadamuz \& A. Rojas Alvarado (JBLspirit!) (Fig. 16C).

EтумоLogy: From the Latin longipedunculatus, "with a long peduncle," in reference to the unusually elongate peduncle of the flower, which can reach $8 \mathrm{~cm}$ in length.

Distribution: Known only from Costa Rica, where it has been recorded from the Caribbean watershed of the Talamanca, Central Volcanic, and Guanacaste mountain chains (Fig. 14).

Habitat and eCology: Epiphytic in partial shade on large branches and trunks of trees, in primary and mature secondary vegetation, with records in lower montane wet, premontane rain, and premontane wet forests at elevations of between 1300-1800 meters. Flowering has been recorded under cultivation in March to June, September, and November.

Echinosepala longipedunculata is most similar to E. aspasicensis, with which it shares the large habit of the plant and the general morphology of the flower. Nevertheless, E. longipedunculata can be recognized by the unusually long peduncle that can reach $8 \mathrm{~cm}$ in length (vs.2.0-3.5 cm in E. aspasicensis), the greenish yellow flowers (vs. purple-brown), the verrucosetuberculate adaxial surface of the sepals (vs. glabrous), and the shorter, truncate, orange lip (vs. one and half times longer, obtuse to acute, purple). 
Whilst the phylogenetic reconstruction based on the ITS region clearly distinguishes between $E$. longipedunculata and E. aspasicensis, the samples of the latter taxon used in our analysis seem to suggest that the concept of E. aspasicensis encompasses two or more cryptic species.

\section{Key to the species of Echinosepala IN Costa Rica}

1. Base of the lip with the callus with a horseshoe-shaped pseudo-glenion

2. Inflorescences produced from the lower nodes of the ramicaul

3. Sheaths of the ramicaul hirsute; sepals echinate abaxially

3a. Sheaths of the ramicaul glabrous; sepals shortly tomentose abaxially

E. expolita

2a. Inflorescences produced from the apex of the ramicaul

4. Leaves of fertile stems $<10$ long; flowers small, synsepal $<1$ long, lip $<4 \mathrm{~mm}$ long

5. The dorsal sepal yellow, the synsepal deep purple, abaxially densely tomentose

6. Ovary and abaxial surface of the sepals tomentose; adaxial surface spiny

6a. Ovary and abaxial surface of the flowers warty; adaxial surface verruculose

7. Peduncle $<3 \mathrm{~cm}$ long; flowers purple-maroon; lip elliptic, acute, purple-red

E. aspasicensis s.l.

7a. Peduncle $>6 \mathrm{~cm}$ long; flower yellow-orange; lip sub rectangular, truncate, yellow

\section{E. longipedunculata}

1a. Base of the lip with the callus smooth to rugulose, without a pseudoglenion

8. Inflorescences produced from the lower nodes of the stem

9. Dorsal sepal narrowly triangular-lanceolate

E. lappiformis

9a. Dorsal sepal broadly oblong

E. stonei

8a. Inflorescence produced from the apex of the stem

10. Leaves ligulate; flowers autogamous, mostly cleistogamous, adaxially warty

E. sempergemmata

10a. Leaves lanceolate; flowers not autogamous, adaxially glabrous

E. uncinata

We take the opportunity of this paper to transfer to Echinosepala a species originally described by Luer (Luer \& Thoerle 2012) as a member of Acianthera, but clearly belonging in Echinosepala based on both its vegetative habit and flower morphology. Zelenko and Bermúdez (2009) recorded E. aspasicensis from Peru, without citing any voucher to support their claim. The present transfer, based on a specimen from the Department of Junín in the Amazonian region of Central Peru, fills the gap in the distribution of the genus Echinosepala noted by Pridgeon (2005a).

\section{Echinosepala biseta (Luer) Pupulin, comb. nov.}

Basionym: Acianthera biseta Luer, Harvard Papers in Botany 17: 333, f. 1. 2012.

TYPE: Peru. Junín, Chanchamayo, near Mina San Vicente, 2000-2800 m, June 2012, collected by Benito Monterrey, E. Morón de Abad 004 (Holotype: USM).
ACKNOwledgments. This manuscript was prepared as part of a dedicatory issue commemorating the ninety-fifth birthday of Carlyle A. Luer, whose extensive work on the Pleurothallidinae is the basis for most current studies in the subtribe. The scientific services of the Costa Rican Ministry of Environment and Energy (MINAE) and National System of Conservation Areas (SINAC) kindly issued the collecting permits under which wild specimens treated in this paper were collected. We are indebted to Diego Bogarín for the profound discussion on the taxonomy and systematic of the Pleurothallidinae. We thank Darha Solano Ulate for her help inking the illustrations of the new species. This research was enabled by the Project 814-A0-052, "Flora Costaricensis, Orchidaceae, subtribe Pleurothallidinae", supported by the Vice-Presidency of Research, Universidad de Costa Rica.

\section{LITERATURE CITED}

Dressler, R. L. (1993). Phylogeny and classification of the orchid family. Cambridge: Cambridge University Press.

Drummond, A.J. \& Rambaut, A. (2007). BEAST: Bayesian evolutionary analysis by sampling trees. 
BMC Evolutianary Biology, 7, 214. Doi: http://dx.doi. org/10.1186/1471-2148-7-214.

Epidendra. (2017). The Global Orchid Taxonomic Network. Jardín Botánico Lankester, Universidad de Costa Rica. Available from http://epidendra.org/taxones/index. html. Consulted on June 2017.

Fawcett, W. (1895). Two new orchids from Jamaica. Journal of Botany, 33, 12.

Fawcett, W. \& Rendle, A. B. (1910). Flora of Jamaica: Orchidaceae. London: British Museum.

IPNI. (2017). The International Plant Names Index. Available from http://www.ipni.org/. Consulted on June 2017.

Karremans, A. P. (2016). Genera Pleurothallidinarum: an updated phylogenetic overview of Pleurothallidinae. Lankesteriana, 16(2), 219-241.

Karremans, A. P., Pupulin, F. \& Gravendeel, B. (2015). Specklinia dunstervillei, a new species long confused with Specklinia endotrachys (Orchidaceae: Pleurothallidinae). PLoS ONE, 10(7), e0131971.

Karremans, A. P., Bogarín, D., Díaz-Morales, M., Fernández, M., Oses, L. \& Pupulin, F. (2016). Phylogenetic reassessment of Acianthera (Pleurothallidinae: Orchidaceae). Harvard Papers in Botany, 21(2), 171187.

Luer, C. A. (1982). Miscellaneous new species and combinations in the Pleurothallidinae. Selbyana, 7, $100-128$.

Luer, C. A. (1992). Icones Pleurothallidinarum IX. Systematics of Myoxanthus. Addenda to Platystele, Pleurothallis subgenus Scopula, and Scaphosepalum (Orchidaceae). Monographs in Systematic Botany from the Missouri Botanical Garden, 44, 1-128.

Luer, C. A. (1995). A re-evaluation of the Pleurothallid subgenera Satyria and Silenia (Orchidaceae). P. 146 in: Icones Pleurothallidinarum XII. Systematics of Brachionidium. Addenda to Dresslerella, Platystele and Porroglossum. Monographs in Systematic Botany from the Missouri Botanical Garden, 57.

Luer, C.A. (1996). Validation of taxa in the Pleurothallidinae. Lindleyana, 1(2), 118.

Luer, C. A. (2003). Pleurothallis. Pp. 386-452 in: Hammel, B. E., Grayum, M. H, Herrera, C. \& Zamora, N. (eds.), Manual de Plantas de Costa Rica. Volumen III: Monocotiledóneas (Orchidaceae-Zingiberaceae). Monographs in Systematic Botany from the Missouri Botanical Garden, 93.

Luer, C. A. (2004). Icones Pleurothallidinarum XXVI. New genera and combinations in the Pleurothallidinae. Monographs in Systematic Botany from the Missouri Botanical Garden 95, 253-265.
Luer, C. A. (2007). Icones Pleurothallidinarum XXIX. A third century of Stelis of Ecuador. Systematics of ApodaProrepentia. Systematics of miscellaneous small genera. Addenda: new genera, species, and combinations. (Orchidaceae). Monographs in Systematic Botany from the Missouri Botanical Garden, 112.

Luer, C. A. \& Thoerle, L. (2012). Miscellaneous New Species in the Pleurothallidinae (Orchidaceae). Harvard Papers in Botany, 17(2), 333-368.

Maddison W.P. \& Maddison, D.R. 2007. Mesquite: a modular system for evolutionary analysis. Mesquite v. 2.72. Available at http://mesquiteproject.org" http:// mesquiteproject.org

Pridgeon, A. M. (2005a). Echinosepala. Pp. 356-358 in: Pridgeon, A. M., Cribb, P. J., Chase, M. W. \& Rasmussen, F. (eds.). Genera Orchidacearum vol. 4. Epidendroideae (Part 1). Oxford, Oxford University Press.

Pridgeon, A. M. (2005b). Echinosepala. Pp. 246-249 in: Pupulin, F. (ed.). Vanishing Beauty. Native Costa Rican Orchids. Vol. 1. Acianthera-Kegeliella. San José, Editorial de la Universidad de Costa Rica.

Pridgeon, A. M. \& Chase, M. W. (2001). A phylogenetic reclassification of Pleurothallidinae (Orchidaceae). Lindleyana, 16, 235-271.

Pridgeon, A. M. \& Chase, M. W. (2002). Nomenclatural notes on Pleurothallidinae (Orchidaceae). Lindleyana, 17(2), 98-101.

Pridgeon, A. M., Solano, R. \& Chase, M. W. (2001). Phylogenetic relationships in Pleurothallidinae (Orchidaceae): combined evidence from nuclear and plastid DNA sequences. American Journal of Botany, $88,2286-2308$.

Rambaut, A. (2009). FigTree v1.3.1. Available at http:// tree.bio.ed.ac.uk/software/" http://tree.bio.ed.ac.uk/ software/

Reichenbach, H. G. (1855). Pleurothallis aspasicensis. Bonplandia, 3, 73.

Schlechter, R. (1923). Brenesia. Repertorium Specierum Novarum Regni Vegetabilis, Beihefte 19, 200.

Staden, R., Judge, D.P. \& Bonfield, J.K. 2003. Analysing Sequences Using the Staden Package and EMBOSS. In: Krawetz, S.A. \& Womble, D.D. (eds.) Introduction to Bioinformatics. A Theoretical and Practical Approach. Totawa, NJ 07512: Humana Press Inc.

Sun, Y., Skinner, D.Z., Liang, G.H. \& Hulbert, H. (1994). Phylogenetic analysis of Sorghum and related taxa using internal transcribed spacers of nuclear ribosomal DNA. Theoretical and Applied Genetics, 89: 26-32.

Zelenko, H. \& Bermúdez, P. (2009). Orchids. Species of Peru. Quito, Ecuador, ZAI Publications. 